\title{
Selective Identification and Quantitative Analysis of Methionine Containing Peptides by Charge Derivatization and Tandem Mass Spectrometry
}

\author{
Gavin E. Reid, ${ }^{*}$ Kade D. Roberts, ${ }^{*}$ and Richard J. Simpson \\ Institute of Medical Research, Parkville, Victoria, Australia \\ Richard A. J. O'Hair \\ School of Chemistry, University of Melbourne, Parkville, Victoria, Australia
}

Joint Proteomics Laboratory, The Ludwig Institute for Cancer Research and The Walter and Eliza Hall

To enable the development of a tandem mass spectrometry (MS/MS) based methodology for selective protein identification and differential quantitative analysis, a novel derivatization strategy is proposed, based on the formation of a "fixed-charge" sulfonium ion on the side-chain of a methionine amino acid residue contained within a protein or peptide of interest. The gas-phase fragmentation behavior of these side chain fixed charge sulfonium ion containing peptides is observed to result in exclusive loss of the derivatized side chain and the formation of a single characteristic product ion, independently of charge state or amino acid composition. Thus, fixed charge containing peptide ions may be selectively identified from complex mixtures, for example, by selective neutral loss scan mode MS/MS methods. Further structural interrogation of identified peptide ions may be achieved by subjecting the characteristic MS/MS product ion to multistage MS/MS $\left(\mathrm{MS}^{3}\right)$ in a quadrupole ion trap mass spectrometer, or by energy resolved "pseudo" $\mathrm{MS}^{3}$ in a triple quadrupole mass spectrometer. The general principles underlying this fixed charge derivatization approach are demonstrated here by MS/MS, MS ${ }^{3}$ and "pseudo" MS $^{3}$ analysis of side chain fixed-charge sulfonium ion derivatives of peptides containing methionine formed by reaction with phenacylbromide. Incorporation of "light" and "heavy" isotopically encoded labels into the fixed-charge derivatives facilitates the application of this method to the quantitative analysis of differential protein expression, via measurement of the relative abundances of the neutral loss product ions generated by dissociation of the light and heavy labeled peptide ions. This approach, termed "selective extraction of labeled entities by charge derivatization and tandem mass spectrometry" (SELECT), thereby offers the potential for significantly improved sensitivity and selectivity for the identification and quantitative analysis of peptides or proteins containing selected structural features, without requirement for extensive fractionation or otherwise enrichment from a complex mixture prior to analysis. (J Am Soc Mass Spectrom 2005, 16, 1131-1150) (c) 2005 American Society for Mass Spectrometry

$\mathrm{P}$ roteomic studies involving the comprehensive identification, characterization, and quantitative analysis of all the gene products, i.e., proteins expressed by a particular cell or tissue type at a given time, together with the systematic characterization of their specific functional interactions, have recently emerged as a means to determine the hitherto unknown functional role of the thousands of genes identified from recent genome sequencing initiatives $[1,2]$. It is

Published online May 31, 2005

Address reprint requests to Dr. G. E. Reid, Department of Chemistry, Michigan State University, 234 Chemistry Building, East Lansing, MI 48824, USA. E-mail: reid@chemistry.msu.edu

* Current address: Department of Chemistry, Michigan State University, East Lansing, MI 48824. widely anticipated that one of the major outcomes of these studies will be a more complete understanding of the processes that control cellular biochemistry, as well as allowing the development of novel therapeutic agents targeted toward specific biomarkers of disease. Substantial progress in the field has been achieved in recent years, primarily via the application of mass spectrometry (MS) instrumentation and associated sample handling methodologies, together with the development of sophisticated bioinformatic tools, for rapid protein identification and characterization [3]. However, there are a number of issues that currently limit the ability of these mass spectrometry based approaches to translate the "promise" of proteomics into "practice". Foremost among these is the significant analytical chal- 
lenge presented by the mixture complexity, dynamic range and diversity of transcriptional, translation, and post translational modifications associated with the proteome, which is in a constant state of spatial and temporal flux throughout the cell cycle.

\section{Mass Spectrometry (MS) Methods for Selective Protein Identification and Quantitative Analysis}

In a typical approach to protein identification and characterization, complex protein mixtures or individual proteins resolved by electrophoretic or chromatographic methods are subjected to proteolysis, and the resultant peptide mixtures then introduced to the mass spectrometer by on-line chromatography. Following determination of their masses, individual peptide ions are then selected for sequence analysis by tandem mass spectrometry (MS/MS) [4]. Subsequently, protein identification may be achieved by database analysis of the uninterrupted product ion spectrum [5], by database searching of a partially derived amino acid "sequence tag" [6], or by "de-novo" sequence analysis [4]. A major limitation of this analysis strategy however, is that proteolytic digestion increases the complexity of the component mixture by up to several orders of magnitude, thereby placing significant demands on the performance of the analytical methodologies employed for peptide separation and analysis. Furthermore, although affinity purification [7] and off- and on-line multidimensional chromatographic [8] approaches have been developed for simplification of these complex peptide mixtures prior to MS, and dynamic exclusion methods $[9,10]$ have been developed to allow greater numbers of distinct peptide ions to be selected for MS/MS analysis, information regarding the identity of proteins represented as low abundance peptides is commonly not obtained, thereby limiting the dynamic range [11].

Issues associated with mixture complexity and dynamic range also present a challenge to the application of mass spectrometry to the quantitative analysis of protein abundances observed between two different states of a biological system, such as that encountered between normal versus diseased cells. To date, the majority of these methods have employed either in vivo metabolic labeling [12-14] or in vitro chemical derivatization [15-34] to introduce a characteristic differential isotopic mass "tag" between two different samples of interest. The samples are then combined and the proteins subjected to proteolysis (this order may be reversed if differential labeling occurs during or following the proteolytic digestion step), and the masses of the resultant peptides determined by MS. By comparing the relative abundances of peptide ions originating from an isotopically enriched sample with those originating from a sample prepared using naturally abundant isotopes, quantitation of differences in protein abundance between the two samples may be obtained. All these methods for quantitation, however, have been based on a common approach for identification of the differential mass "signature" between the two samples, i.e., by mass analysis of their intact peptide precursor ions.

Limitations to this general analysis strategy may be encountered, therefore, when (1) separation of the differentially labeled "light" and "heavy" peptides occurs during chromatographic fractionation of the peptide mixture [35, 36], (2) the $\mathrm{m} / \mathrm{z}$ values of differentially labeled peptide ions overlap with nonlabeled peptide components present in the mixture, or (3) one or both of the differentially labeled peptide ions of interest are present at, or below, the limit of detection of the mass spectrometer [37]. The use of ${ }^{13} \mathrm{C}$ instead of ${ }^{2} \mathrm{H}$ labeling has been employed to eliminate the deuterium isotope effect responsible for the first of these limitations [33]. The second limitation has been at least partially addressed by the application of strategies for selective enrichment of labeled peptides prior to MS analysis, via affinity purification [15] or solid phase capture [34], or by methods for extensive multidimensional chromatographic fractionation of peptide mixtures prior to analysis [38, 39]. To date, however, limitations associated with the detection of low abundance differentially labeled peptide ions via conventional MS based methods have proven difficult to address.

\section{Tandem Mass Spectrometry (MS/MS) Methods for Selective Protein Identification and Quantitative Analysis}

Recently, an MS/MS based "tandem mass tag" approach for differential quantitative protein analysis has been described that holds promise in addressing this problem [40]. This method is based on measurement of the relative abundances of characteristic isotopically encoded low mass product ions formed by MS/MS from N-terminally derivatized peptides. Similar approaches, employing precursor ion or neutral loss MS/MS scan modes [41], whereby the mass spectrometer is set to detect a characteristic low mass product ion, or a characteristic product ion offset by a given mass from the selected precursor, respectively, have been extensively employed in the past for the selective identification of peptide ions containing certain structural features (e.g., particular amino acid residues [42], post-translational modifications [43-49], or chemical cross linking agents [50]). Because of the reduction in chemical noise associated with the MS/MS experiment, these methods have been demonstrated to yield greater specificity and increase sensitivity by 1 to 2 orders of magnitude over conventional MS based detection methods, and to enable the detection of low abundance precursor ions that may not otherwise be apparent in the MS experiment, i.e., below the level of chemical noise [37]. One of the major limitations of all these methods, however, is that the desired fragmentation pathway giving rise to the product ion of interest is typically only one of many dissociation channels, 
thereby "diluting" the spectrum and limiting the dynamic range.

The reason for a desired fragmentation pathway often not yielding a dominant product ion may be rationalized by taking into consideration the generally accepted mechanisms and other factors (such as peptide ion charge state and amino acid composition) known to be responsible for the gas-phase dissociation reactions of protonated peptide ions. Under low-energy collisional activation conditions, the cleavage of most bonds within a protonated peptide ion is thought to require localization of an ionizing proton at the cleavage site. Fragmentation then proceeds via "charge-directed" neighboring group participation mechanisms involving nucleophilic attack from an adjacent functional group [51-54]. The formation of product ions resulting from "enhanced" cleavage at the N-terminal side of proline residues has been consistently noted in the literature, presumably because of the higher local proton affinity of the proline imide bond compared with a conventional amide bond. However, consistent with the idea that the strongly basic guanidino side chain of arginine residues may act to strongly "sequester" ionizing protons, thereby limiting their ability to be transferred along the peptide backbone to initiate cleavage by charge-directed pathways, a recent report has demonstrated that enhanced proline cleavage is only observed as a dominant process under conditions where the number of ionizing protons is greater than the number of arginine residues contained within the peptide ion [55]. Indeed, under conditions where the number of ionizing protons is less than or equal to the number of arginine residues within the peptide ion, enhanced cleavages at other sites along the peptide backbone via "charge-remote" mechanisms, for example at the Cterminal side of aspartic acid residues or at the side chains of methionine sulfoxide residues, are commonly observed [55, 56].

The derivatization reagent employed in the "tandem mass tag" strategy described above contains a fragmentation "enhancement" group consisting of a proline residue to promote cleavage within the label during MS/MS, as well as a "sensitization" group containing a guanidino group to promote formation of a characteristic protonated low mass product ion following the fragmentation reaction [40]. However, the presence of the guanidino "sensitization" group may actually act to limit proton mobility, and thereby hinder the desired fragmentation pathway from proceeding. Therefore, the formation of abundant low mass product ions characteristic of "tandem mass tag" derivatized peptides are only expected for a sub-set of the total peptide ions presented to the mass spectrometer for dissociation.

Here, to address this problem and to facilitate the development of a general MS/MS based approach for selective protein identification and differential quantitative analysis, we propose a novel derivatization strategy, termed selective extraction of labeled entities by charge derivatization and tandem mass spectrometry
(SELECT), that is based on the formation of a "fixedcharge" on the side-chain of a selected amino acid residue contained within a protein or peptide of interest. Although fixed charge derivatization strategies for peptides have been used previously in conjunction with MS/MS for sequencing applications, most prior work has been limited to derivatization of the $\mathrm{N}$ - and Ctermini, as well as lysine and arginine side chains, and has been focused on directing fragmentation toward the formation of a particular series of backbone cleavage derived sequence ions (i.e., maximizing sequence coverage) [57-62]. In contrast, the MS/MS dissociation of peptide ions containing the fixed charge derivatives described here are directed toward the exclusive formation of a single characteristic side chain product ion, independently of the amino acid composition, proton mobility, or precursor ion charge state. These fixed charge containing peptide ions may therefore be readily identified from complex mixtures, for example, by selective neutral loss scan mode MS/MS methods. Further structural interrogation of peptide ions identified by the fixed charge derivatization approach may be achieved by subjecting the characteristic MS/MS product ion to multistage MS/MS (MS ${ }^{3}$ ) in a quadrupole ion trap mass spectrometer, or by energy resolved "pseudo" $\mathrm{MS}^{3}$ in a triple quadrupole mass spectrometer. Incorporation of "light" and "heavy" isotopically encoded labels into the fixed-charge derivatives also facilitates the application of this MS/MS method to the quantitative analysis of differential protein expression. The SELECT fixed-charge derivatization approach thereby offers the potential for significantly improved sensitivity and selectivity for the identification and quantitative analysis of peptides or proteins containing certain structural features, without the requirement for extensive fractionation or otherwise enrichment from a complex mixture prior to analysis.

\section{Materials and Methods}

\section{Materials}

The synthetic peptides GAILMGAILA, GAILMGAILK, GAILMGAILR, VTMGHFCNFGK, and VTMGHFDNFGR were purchased from Auspep (Melbourne, Australia). Iodomethane, iodoethane, iodobenzene, iodomethylbenzene, $d_{5}$-acetophenone, and poly(4-vinylpyridinium tribromide) were obtained from Aldrich (Castle Hill, Australia). Phenacylbromide was purchased from Fluka (Castle Hill, Australia). Iodoacetic acid and iodoacetamide were from Sigma (St. Louis, MI). Methanol, and acetonitrile (Chromar grade) were purchased from Mallinkrodt (Paris, KY). Acetic acid was obtained from BDH Laboratories (Poole, United Kingdom). All solutions were prepared using deionized water purified by a tandem Milli-Q and Milli-RO system (Millipore, Bedford, MA). Unless stated otherwise, all reagents were AR grade and used as supplied without further purification. 


\section{Synthesis of $2^{\prime}, 3^{\prime}, 4^{\prime}, 5^{\prime}, 6^{\prime}-{ }^{2} \mathrm{H}_{5}$-Phenacylbromide}

$2^{\prime}, 3^{\prime}, 4^{\prime}, 5^{\prime}, 6^{\prime}-{ }^{2} \mathrm{H}_{5}$-phenacylbromide was synthesized according to the method of Frechet et al. [63] ${ }^{\circ}$ Briefly, $2^{\prime}, 3^{\prime}, 4^{\prime}, 5^{\prime}, 6^{\prime}-{ }^{2} \mathrm{H}_{5}$-acetophenone ( $\left.1 \mathrm{mmol}, 1.25 \mathrm{~mL}\right)$ was added to poly(4-vinylpyridinium tribromide) $(4.8 \mathrm{~g}, \sim 3$ meq $\mathrm{Br}_{3}^{-} / \mathrm{g}$ resin) in $30 \mathrm{~mL}$ methanol, then allowed to react with stirring at room temperature for $4 \mathrm{~h}$. The resultant $\alpha$-bromo ketone was obtained in pure form by filtration of the reaction mixture, followed by evaporation of the solvent and recrystallization prior to use.

\section{Side Chain Fixed-Charge Derivatization of Methionine-Containing Peptides}

Side chain fixed-charge sulfonium ion derivatives of synthetic methionine-containing model "tryptic" peptides were produced by the addition of $10 \mu \mathrm{L}$ of a $1 \mathrm{M}$ solution of alkylating reagent to $100 \mu \mathrm{g}$ of peptide dissolved in $100 \mu \mathrm{L}$ of aqueous $20 \%$ HOAc containing $30 \% \mathrm{CH}_{3} \mathrm{CN}$. The reaction was allowed to proceed for $24 \mathrm{~h}$ at room temperature after which the sample was diluted then introduced to the mass spectrometer with no further purification.

\section{Mass Spectrometry}

Mass spectrometric analysis was performed using (1) quadrupole ion trap (Thermo-Finnigan model LCQ, San Jose, CA), (2) quadrupole-time-of-flight (Micromass model Q-TOF2, Manchester, UK), or (3) triple quadrupole (Thermo-Finnigan model TSQ, San Jose, CA) mass spectrometers, each equipped with electrospray ionization (ESI) interfaces.

\section{Quadrupole Ion Trap Mass Spectrometry}

Samples $\left(10 \mathrm{pmol} / \mu \mathrm{L}\right.$ in 50:50:1 $\left.\mathrm{H}_{2} \mathrm{O} / \mathrm{CH}_{3} \mathrm{CN} / \mathrm{HOAc}\right)$ were introduced to the mass spectrometer by electrospray ionization at $2 \mu \mathrm{L} / \mathrm{min}$. ESI conditions were optimized to maximize the intensity of the ion of interest and to minimize the extent of "in-source" fragmentation. Typical conditions were: spray voltage $-5 \mathrm{kV}$, nitrogen sheath gas, $30 \mathrm{psi}$, heated capillary temperature $150{ }^{\circ} \mathrm{C}$. MS/MS and $\mathrm{MS}^{3}$ experiments were performed on mass selected ions using standard isolation and excitation procedures. All spectra shown were the average of 10 scans.

\section{Quadrupole-Time-Of-Flight Mass Spectrometry}

Samples (10 pmol/ $\mu \mathrm{L}$ in 50:50:1 $\mathrm{H}_{2} \mathrm{O} / \mathrm{CH}_{3} \mathrm{CN} / \mathrm{HOAc}$ ) were introduced to the mass spectrometer by electrospray ionization at $1 \mu \mathrm{L} / \mathrm{min}$. Electrospray interface conditions were optimized to maximize the intensity of the ion of interest. Typical conditions were: spray voltage, $-4.5 \mathrm{kV}$; nitrogen source gas, $1 \mathrm{psi}$; cone gas, 100 (arbitrary units); source temperature, $50^{\circ} \mathrm{C}$; desolvation temperature, $150^{\circ} \mathrm{C}$; cone voltage, $50 \mathrm{~V}$ (for singly charged ions), $30 \mathrm{~V}$ (for doubly charged ions), and $20 \mathrm{~V}$ (for triply charged ions). Energy resolved CID MS/MS experiments were acquired using argon as the inert collision gas at a pressure of 10 psi. The collision energy was ramped from 4 to $58 \mathrm{~V}$ in $1 \mathrm{~V}$ increments for singly charged ions, from 4 to $20 \mathrm{~V}$ in $1 \mathrm{~V}$ increments for doubly charged ions, and from 20 to $46 \mathrm{~V}$ in $2 \mathrm{~V}$ increments for triply charged ions. Spectra were acquired using the V-optics mode of the time-of-flight mass analyzer. Spectra obtained at each collision energy value were the average of 10 scans.

\section{Triple Quadrupole Mass Spectrometry}

Samples $\left(1 \mathrm{pmol} / \mu \mathrm{L}\right.$ in 50:50:1 $\left.\mathrm{H}_{2} \mathrm{O} / \mathrm{CH}_{3} \mathrm{CN} / \mathrm{HOAc}\right)$ were introduced to the mass spectrometer by a home built nano-electrospray ionization source at a flow rate of $200 \mathrm{~nL} / \mathrm{min}$. The spray voltage was maintained at $-1.8 \mathrm{kV}$. The heated capillary temperature was $150^{\circ} \mathrm{C}$. The argon collision gas pressure was maintained at 1.5 mTorr. The instrument was operated under unit resolution conditions. Neutral loss mode MS/MS scans (neutral losses of 83 and 85.5 Thomson (Th) for $\mathrm{d}_{0}$ - and $\mathrm{d}_{5}$-containing doubly charged ions, and 55.3 and $57 \mathrm{Th}$ for $\mathrm{d}_{0^{-}}$and $\mathrm{d}_{5}$-containing triply charged ions) were performed at collision energies of 18 and $13 \mathrm{~V}$, respectively. Product ion CID MS/MS spectra of peptide ions selectively identified by neutral loss scans were then acquired at 18 and $31 \mathrm{~V}$ for doubly charged ions and 13 and $18 \mathrm{~V}$ for triply charged ions. All spectra shown were the average of 20 scans.

On-line capillary RP-HPLC was performed using (1) a $200 \mu \mathrm{m}$ i.d. $\times 150 \mathrm{~mm}$ fused silica column, packed with Brownlee RP-300, $7 \mu \mathrm{m}$ dimethyloctyl silica, developed at a flow rate of $3.6 \mu \mathrm{L} \mathrm{min}{ }^{-1}$ using a linear 60 min gradient from $0-100 \%$ B, or (2) a $75 \mu$ m i.d. $\times 150$ mm fused silica column, packed with Vydac C4, developed at a flow rate of $200 \mathrm{~nL}$ min $^{-1}$ using a linear 60 min gradient from $0-100 \%$ B. In both cases, Solvent A was $0.1 \mathrm{M}$ HOAc, and Solvent B was $0.1 \mathrm{M} \mathrm{HOAc}$ containing $60 \% \mathrm{CH}_{3} \mathrm{CN}$.

\section{Results and Discussion}

The general principles underlying the SELECT side chain fixed charge derivatization approach for protein identification and differential quantitation are demonstrated here by MS/MS and MS $^{3}$ analysis of fixedcharge sulfonium ion derivatives of peptides containing methionine. Analysis of release 45.2 of the SWISS-PROT database indicates that while the occurrence of methionine residues in the database is only $2.37 \%, 96.9 \%$ of the individual protein entries within the database contain at least one methionine residue, thereby satisfying the criteria that approaches for selective protein identification and quantitative analysis should minimize the number of peptides to be identified, while providing comprehensive proteome coverage.

Identification of methionine-containing peptides via 
<smiles></smiles>

[M]<smiles>[R][As]([R])(C)CCC(NC(C)=O)C(=O)NC</smiles>

$$
\underset{-\mathrm{CH}_{3} \mathrm{SR}_{1}}{\stackrel{\text { (iii) } \mathrm{CID}}{\longrightarrow}} \quad\left[\mathrm{M}+\mathrm{nH}-\mathrm{CH}_{3} \mathrm{SR}_{1}\right]^{(\mathrm{n}+1)+}
$$

$\left[\mathrm{M}^{+}+\mathrm{nH}+\mathrm{R}_{1}\right]^{(\mathrm{n}+1)+}$

Scheme 1
CID MS/MS of their sulfonium ion fixed-charge derivatives is attractive for several reasons The chemistry and biological applications of sulfonium ions are well documented ${ }^{\circ}\left[64^{\circ}-78\right] .{ }^{\circ}$ The ${ }^{\circ}$ alkylation ${ }^{\circ} f^{\circ}$ methionine ${ }^{\circ}$ residues in proteins and peptides is specific at low $\mathrm{pH}$ regardless of the alkylating reagent used, because the rate of alkylation of the thioether sulfur atom of the methionine side chain is virtually independent of $\mathrm{pH}$ $\left(\text { even }^{\circ} \text { down }^{\circ} \text { to }^{\circ} \mathrm{pH} 1\right)^{\circ}\left[65,{ }^{\circ} 66\right] .{ }^{\circ}{ }^{\circ}{ }^{\circ}$ contrast, $^{\circ}$ the ${ }^{\circ}$ reactivity of all other nucleophilic functional groups (e.g., cysteine, lysine and histidine residues) decreases at low $\mathrm{pH}$ because of the protonation. In a previous experiment aimed at elucidating the gas-phase fragmentation reactions of protonated amino acids by MS/MS, fixedcharge side chain sulfonium ion derivatives of methionine and S-methyl cysteine were observed to fragment exclusively via neutral loss of the side chain $\mathrm{CH}_{3} \mathrm{SR}_{1}$, where $R_{1}$ 。was ${ }^{\circ}{ }^{\circ}$ substituted ${ }^{\circ}$ alkyl ${ }^{\circ}$ group $\left.979,{ }^{\circ} 80\right]^{\circ}$ (Scheme 1). This loss has also been observed previously for peptides $^{\circ}[81]^{\circ}$ and $^{\circ}$ proteins $^{\circ}[82]$.

\section{Solution and Gas-Phase Requirements for Fixed- Charge Sulfonium Ion Derivatization of Methionine Containing Peptides}

In order for the fixed charge derivatization strategy to be successful, both the solution-phase reactivity and the gas-phase ion chemistry of the resultant sulfonium ions must be considered. The requirements for sulfonium ion formation in solution include (1) that reactions should be easy to perform using readily available alkylating reagents, (2) that the derivatization reaction should be specific to the desired amino acid residue and proceed to completion, and (3) that the resultant sulfonium ion be $^{\circ}$ chemically and thermally stable $\{65,83,84]$. Many of the potentially useful reagents of interest are commercially available. Others may be synthesized from commercially available precursors by using simple methods described in the literature. For example, stable isotope labeled $2^{\prime}, 3^{\prime}, 4^{\prime}, 5^{\prime}, 6^{\prime}-{ }^{2} \mathrm{H}_{5}$-phenacylbromide may be readily prepared from $2^{\prime}, 3^{\prime}, 4^{\prime}, 5^{\prime}, 6^{\prime}-{ }^{2} \mathrm{H}_{5}-$ acetophenone in a one-step process as outlined in the Materials and Methods section above.

The reactivity and stability of a range of potential alkylating reagents for methionine side chain fixedcharge sulfonium ion formation, including iodomethane, iodoethane, iodobenzene, iodomethylbenzene, iodoacetic acid, iodoacetamide, and phenacylbromide have been evaluated by reaction with the model peptide GAILMGAILK. The peptide was reacted with a 100-fold molar excess of each alkylating reagent for $4,8,16$, or $32 \mathrm{~h}$ before being analyzed by mass spectrometry to determine the extent of reaction. After $16 \mathrm{~h}$, only the phenacyl ${ }^{\circ}$ derivative ${ }^{\circ}$ ad $^{\circ}$ reacted $^{\circ}$ to ${ }^{\circ}$ completion $^{\circ}$ [85-87]. The ethyl derivative was found to have the least reactivity and stability in solution (only $1 \%$ reaction after $16 \mathrm{~h}$ ). All other reagents ranged in reactivity between these two extremes. The phenacyl sulfonium ion derivative was found to be stable in solution for several weeks without significant degradation. All the sulfonium ions examined, including those with poor reactivity in solution, were found to be sufficiently stable to allow their introduction to the mass spectrometer by electrospray ionization.

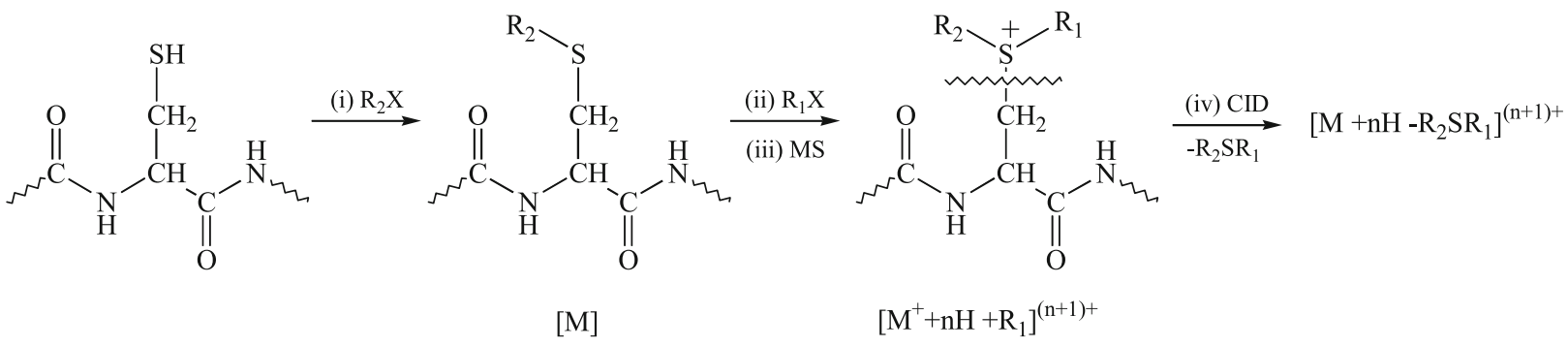

Scheme 2 


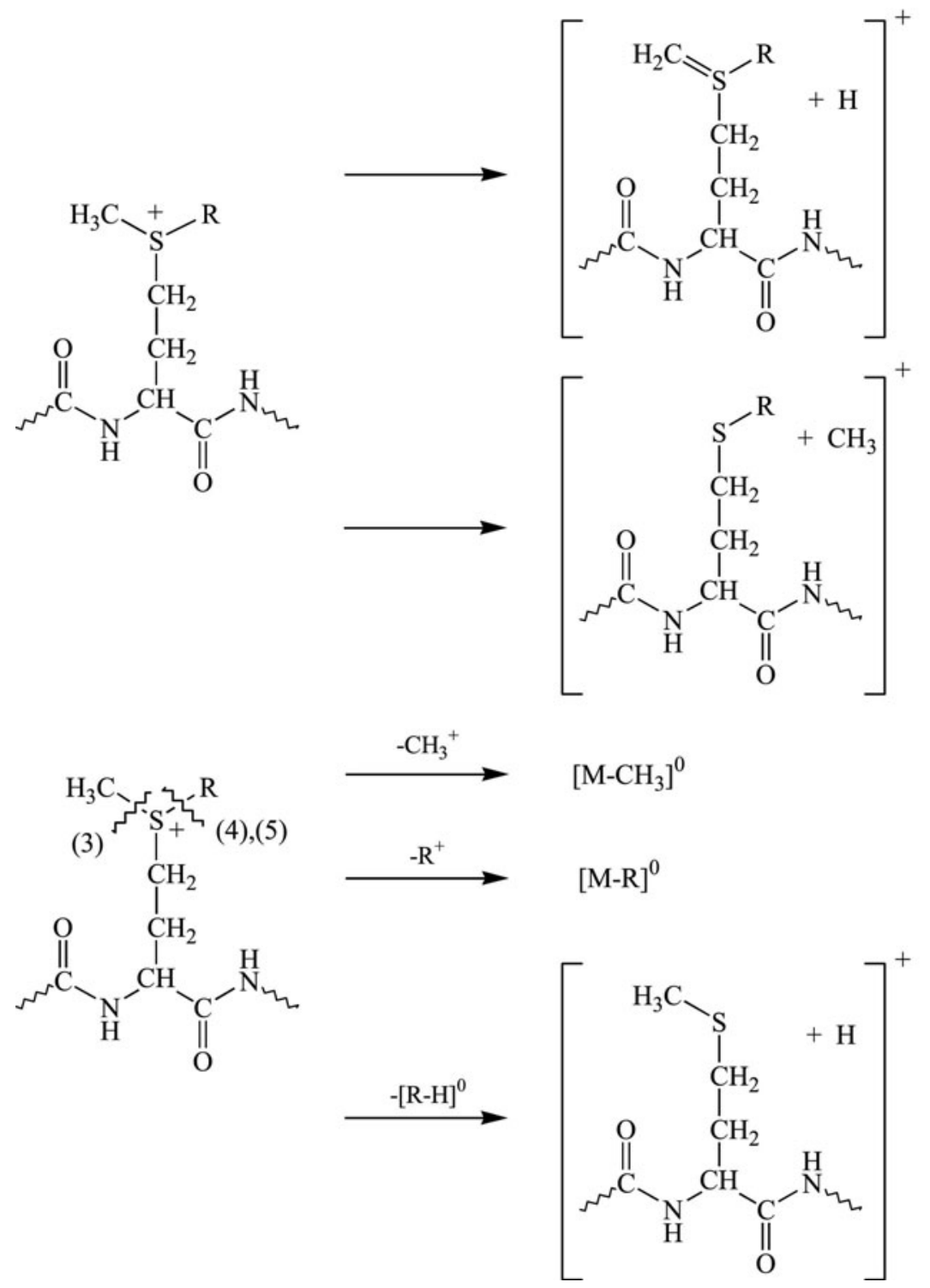

Scheme 3

As free $\mathrm{SH}$ groups of cysteine residues have been shown to effect the reversal of the alkylation of methionine'residues [88], and 'transfer ${ }^{\circ}$ of a methyl group from a sulfonium salt to a free sulfhydryl acceptor is a well known $^{\circ}$ possible $^{\circ}$ side $^{\circ}$ reaction $^{\circ}\left[89^{\circ} 91\right]^{\circ},{ }^{\circ}$-alkylation ${ }^{\circ}$ of cysteine residues prior to methionine sulfonium ion formation may be required. However, S-alkylation of a cysteine residue to yield the derivative $\left(-\mathrm{CHCH}_{2} \mathrm{SR}_{2}\right)$ [step (i) of Scheme 2] may also result in the subsequent formation of a fixed charge sulfonium ion derivative under identical conditions to those employed for alkylation of methionine, provided that the initial S-alkyl derivative is stable to sulfonium ion formation [step (ii) in Scheme 2]. Although differentiation between sulfonium ion derivatives of methionine and stable sulfonium ion derivatives of S-alkyl cysteine residues may be readily achieved during MS/MS by using an alkyl group $R_{2}$ which is NOT a methyl group, initial cysteine alkylation conditions could also be chosen so that the S-alkyl derivative is not stable to sulfonium ion formation, thereby allowing specific derivatization of methionine containing peptides only.

A key requirement of this work is that the fixed charge derivatives dissociate to yield a single characteristic product ion via cleavage of the $\gamma-\mathrm{CH}_{2}-\mathrm{S}$ linkage adjacent to the fixed charge upon MS/MS fragmentation (Scheme 1). Thus, side reactions such as charge migration via intramolecular proton transfer, alkyl group transfer, as well as breaking of bonds to give stable $^{\circ}$ alkyl $^{\circ}$ cations $^{\circ}$ or $^{\circ}$ alkenes $^{\circ}$ must $^{\circ}$ be $^{\circ}$ avoided $^{\circ}[92-$ 100]. Proton'transfer ${ }^{\circ}\left(\text { Scheme }^{\circ} \text {, }^{\circ} \text { Pathway }{ }^{\circ}\right)^{\circ}$ would $^{\circ}$ give an sulfur ylide. Although the acidity of the $\left(\mathrm{CH}_{3}\right)_{3} \mathrm{~S}^{+}$ion [or the proton affinity of the conjugate base $\left.\left(\mathrm{CH}_{3}\right)_{2} \mathrm{~S}\left(\mathrm{CH}_{2}\right)\right]$ is unknown, sulfur ylides may be formed in solution by deprotonating sulfonium ions with bases such as hydroxide ion ( $\mathrm{HO}-)$ or alkyl 

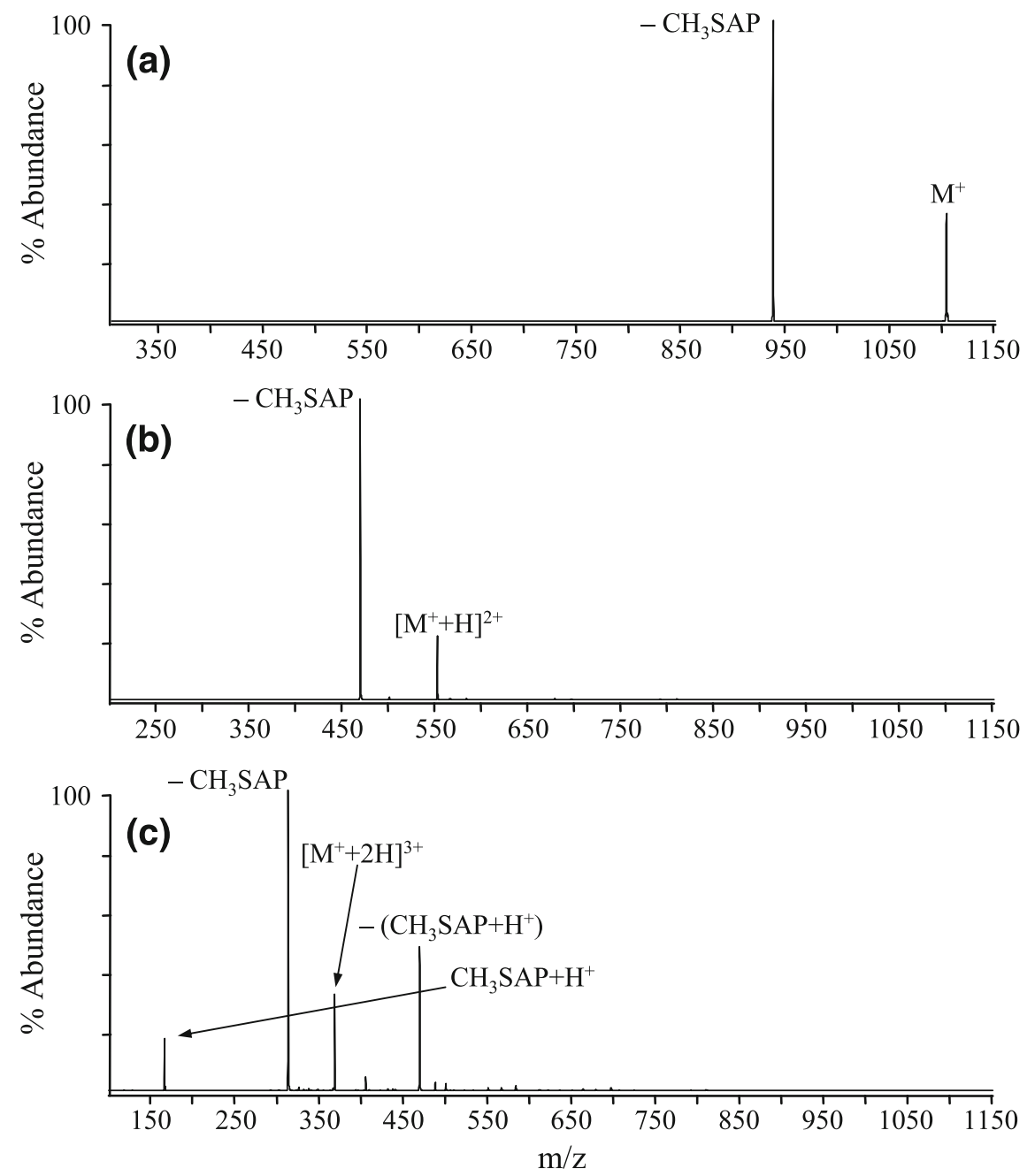

Figure 1. Analysis of a methionine side chain phenacyl sulfonium ion fixed charge derivative of GAILMGAILK by quadrupole ion trap CID MS/MS. (a) CID MS/MS product ion spectrum of the $\mathrm{M}^{+}$ ion. (b) CID MS/MS product ion spectrum of the $\left[\mathrm{M}^{+}+\mathrm{H}\right]^{2+}$ ion. (c) CID MS/MS product ion spectrum of the $\left[\mathrm{M}^{+}+2 \mathrm{H}\right]^{3+}$ ion.

lithium $^{\circ}$ reagents $^{\circ}[92]^{\circ}{ }^{\circ}$ Alkyl $^{\circ}$ transfer $^{\circ}\left(\right.$ Scheme $^{\circ} 3,{ }^{\circ}$ Pathway 2 ) is not likely to be a problem since intramolecular $\mathrm{S}_{\mathrm{N}} 2$ reactions rarely occur due to high energy transition states $^{\circ}\left(\right.$ colinear $^{\circ}$ geometry $^{\circ}[93] .^{\circ}$ The $^{\circ}$ solution $^{\circ}$ phase methyl cation affinities (MCAs) of some biological sulfur $^{\circ}$ systems ${ }^{\circ}$ have $^{\circ}$ been $^{\circ}$ studied $^{\circ}[94]^{\circ}{ }^{\circ}$ Unfortunately, gas-phase MCAs are limited to experimental and theoretical ${ }^{\circ}$ estimates ${ }^{\circ}{ }^{\circ}{ }^{\circ}$ dimethylsulfide $[95]^{\circ}$ and ${ }^{\circ}$ theoretical estimates $^{\circ}$ of $^{\circ}$ some $^{\circ}$ other $^{\circ}$ sulfides $^{\circ}[96] .^{\circ}$ The $^{\circ}$ bond strengths of other breaking alkyl groups appear to be unknown in both the condensed phase and the gas phase. There have, however, been several studies on the fragmentation reactions of sulfonium ions as studied by mass $^{\circ}$ spectrometry ${ }^{\circ}[97-100] .{ }^{\circ}$ Scheme $^{\circ} 3\left(\text { Pathway }^{\circ} 3\right)^{\circ}$ is highly unlikely given that the least stable carbocation is formed $\left(\mathrm{CH}_{3}^{+}\right)$. Problems associated with Scheme 3 (Pathways 4 and 5) can be avoided by choosing an $\mathrm{R}$ group that does not yield a stable ion (e.g., avoid benzyl groups etc.) and does not form an alkene (e.g., avoid ethyl or substituted ethyl groups and higher homo- logues), respectively. As the phenacylbromide derivatization reagent allows these side reactions to be largely avoided, this reagent has been employed for the remaining studies described herein.

\section{Examination of the Fragmentation Behavior} of Fixed-Charge Phenacyl Sulfonium Ion Derivatives of Methionine Containing Peptides

CID MS/MS and $M S^{3}$ in a quadrupole ion trap mass spectrometer. The gas-phase fragmentation behavior of the fixed charge phenacyl sulfonium ion derivatives of the methionine containing peptides, GAILMGAILX (where $X$ is either alanine, lysine, or arginine), VTMGHFCNFGK, VTMSHFWNFGK, and VTMGHFDNFGR have been examined by CID MS/MS in a quadrupole ion trap mass spectrometer. Illustrative of the general observations made to date regarding this fragmentation behavior ${ }^{\circ}$ re $^{\circ}$ the ${ }^{\circ}$ data $^{\circ}$ shown ${ }^{\circ}$ in ${ }^{\circ}$ Figures $1-6^{\circ}$ and ${ }^{\circ}$ Figures 

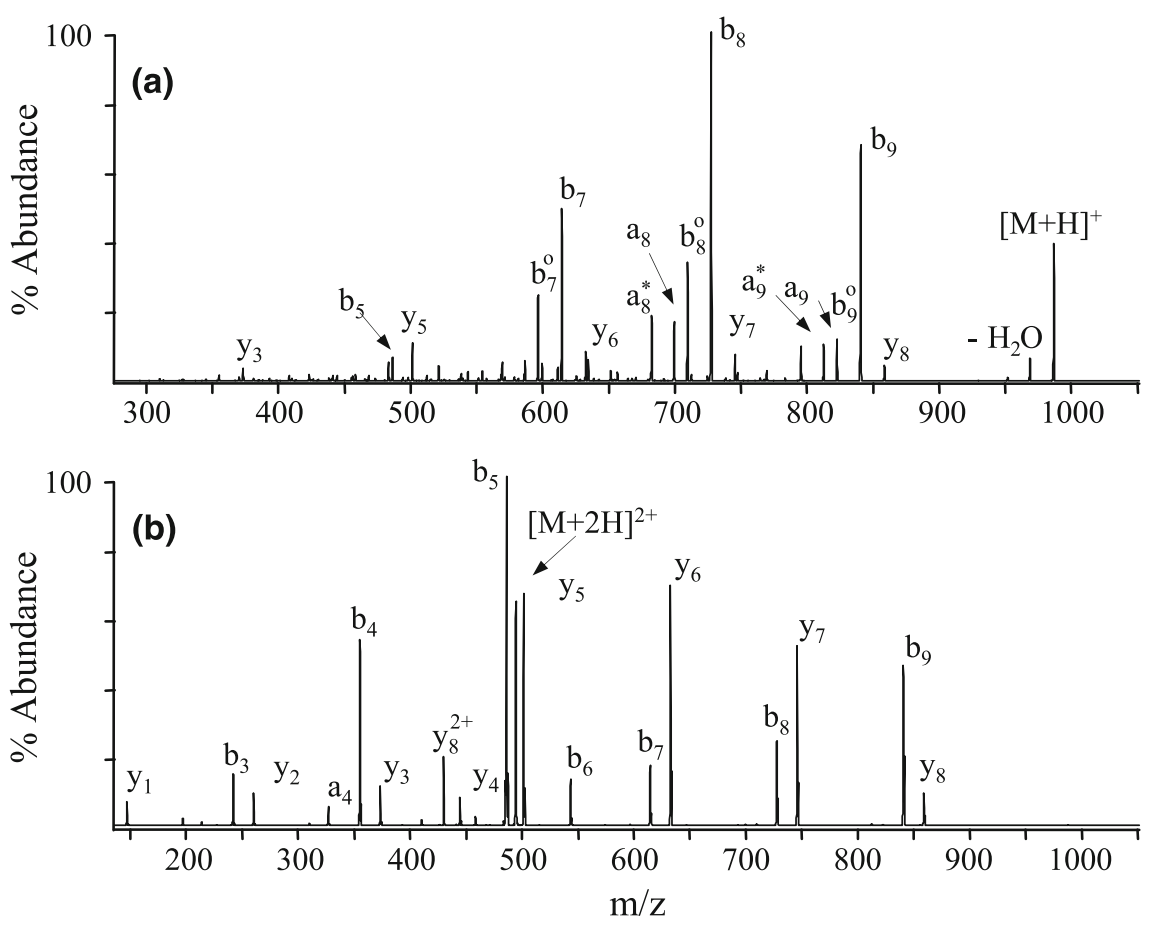

Figure 2. Analysis of GAILMGAILK by quadrupole ion trap mass spectrometry. (a) CID MS/MS product ion spectrum of the $[\mathrm{M}+\mathrm{H}]^{+}$ion. (b) CID MS/MS product ion spectrum of the $[\mathrm{M}+2 \mathrm{H}]^{2+}$ ion.

S1-S. ${ }^{\circ}$ Figure $^{\circ} 1^{\circ}$ shows $^{\circ}$ the ${ }^{\circ} \mathrm{CID}^{\circ} \mathrm{MS} / \mathrm{MS}^{\circ}$ product $^{\circ}$ ion spectra for the singly, doubly, and triply charged phenacyl sulfonium ion derivatives of the model "tryptic" peptide GAILMGAILK, each containing a single fixed-charge corresponding to the sulfonium ion plus 0 , 1 , or 2 additional protons, respectively. In each case, the overwhelmingly dominant fragmentation pathway corresponded to selective cleavage of the $\gamma-\mathrm{CH}_{-}-\mathrm{S}$ bond at the site of the fixed-charge on the methionine side chain, resulting in the neutral loss of phenacyl methyl sulfide (166 Da, $\left.\mathrm{CH}_{3} \mathrm{SCH}_{2} \mathrm{COC}_{6} \mathrm{H}_{5}\right)^{\circ}$ (labeled in ${ }^{\circ}$ Figure 1 as $\left.-\mathrm{CH}_{3} \mathrm{SAP}\right)$. This is in marked contrast to that observed for CID MS/MS of the singly and doubly protonated ions of the unmodified GAILMGAILK peptide $^{\circ}\left(\right.$ Figure $^{\circ} 2 a^{\circ}$ and $^{\circ} b,{ }^{\circ}$ respectively), ${ }^{\circ}$ where ${ }^{\circ}$ the ${ }^{\circ}$ formation of a series of $b$ - and $y$-type ions resulting from dissociations occurring along the peptide backbone were observed. The triply charged state of the fixed charge $^{\circ}$ sulfonium $^{\circ}$ ion $^{\circ}$ containing $^{\circ}$ peptide $^{\circ}\left(\right.$ Figure $^{\circ} 1 \mathrm{c}$ ) was the only partial exception, where some charged side chain loss of protonated phenacyl methyl sulfide was also observed. The MS/MS product ion spectra obtained by CID MS/MS of the singly and doubly charged forms of GAILMGAILA and the singly, doubly, and triply charged forms of GALMGAILR, following phenacyl sulfonium ion formation, are contained in the supplemental material accompanying this manuscript and are available from the authors upon request. The fragmentation behavior of these ions was essentially identical to that described above for the GAILMGAILK peptide ions. Thus, in contrast to that typically observed for the fragmentation of protonated peptide ions ${ }^{\circ}[55],{ }^{\circ}$ there ${ }^{\circ} \operatorname{does}^{\circ}$ not $^{\circ}$ appear $^{\circ}$ to $^{\circ}$ be $^{\circ}$ any $^{\circ}$ significant charge state or basic amino acid composition dependence to the fragmentation behavior of the side chain fixed charge sulfonium ion containing peptides.

The specificity of sulfonium ion formation at methionine residues under low $\mathrm{pH}$ conditions, even in the presence of an S-alkyl cysteine amino acid, is shown $^{\circ}$ in $^{\circ}$ Figure $^{\circ} 3$ a. $^{\circ}$ This $^{\circ}$ figure $^{\circ}$ shows $^{\circ}$ the ${ }^{\circ}$ mass spectrum obtained from ESI of the synthetic peptide VTMGHFCNFGK following alkylation of the cysteine residue with iodoacetamide under basic $\mathrm{pH}$ conditions, then overnight reaction with phenacylbromide under acidic conditions to yield the sulfonium ion. Complete conversion of the peptide to the sulfonium ion derivative was observed, with no evidence for side reactions or additional alkylation products. CID MS/MS of the doubly and triply charged precursor ions $^{\circ}\left(\right.$ Figure $^{\circ} 3 \mathrm{~b}^{\circ}$ and $^{\circ} \mathrm{c}^{\circ}$, respectively) ${ }^{\circ}$ resulted ${ }^{\circ}$ in $^{\circ}$ the exclusive loss of phenacyl methyl sulfide, indicative of selective sulfonium ion formation at the thiomethyl side chain of the methionine residue. Thus, S-carboxyamidomethyl cysteine residues are not reactive to sulfonium ion formation. Once again, the selective fragmentation behavior is in stark contrast to that observed from dissociation of the unmodified peptide ${ }^{\circ}$ ions $^{\circ}\left(\right.$ Figure $\left.^{\circ} 4\right),{ }^{\circ}$ where ${ }^{\circ}$ fragmentation ${ }^{\circ}$ occurring along the peptide backbone to yield $b$ - and y-type ions was observed as the major dissociation pathway. The MS/MS product ion spectra obtained by CID MS/MS of the doubly and triply charged 

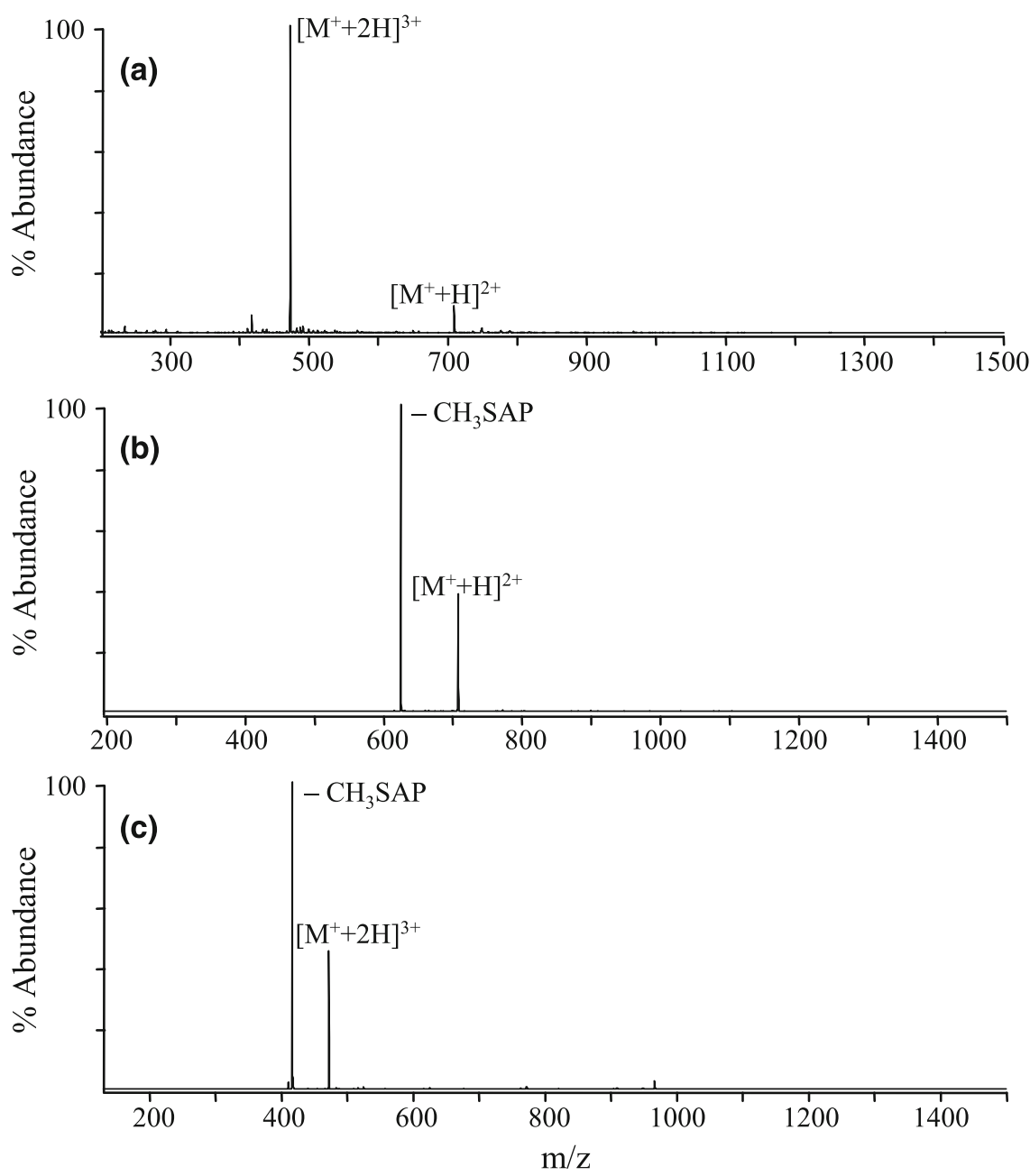

Figure 3. Analysis of a methionine side chain phenacyl sulfonium ion fixed charge derivative of VTMGHFC(S-carboxyamidomethyl)NFGK by quadrupole ion trap MS and CID MS/MS. (a) Mass spectrum obtained by ESI. (b) CID MS/MS product ion spectrum of the $\left[\mathrm{M}^{+}+\mathrm{H}\right]^{2+}$ ion. (c) CID MS/MS product ion spectrum of the $\left[\mathrm{M}^{+}+2 \mathrm{H}\right]^{3+}$ ion.

forms of VTMGHFDNFGR, following sulfonium ion formation by reaction with phenacylbromide, are contained in the supplemental material accompanying this manuscript and are available from the authors upon request. The fragmentation behavior of these ions were essentially identical to those described above for the VTMGHFCNFGK peptide, indicating that the potentially competing reaction involving enhanced "charge remote" fragmentation at the C-terminal side of the aspartic acid residue does not compete with the "charge directed" loss of the fixed charge on the methionine side chain.

Potential mechanisms for the neutral loss of $\mathrm{CH}_{3} \mathrm{SCH}_{2} \mathrm{COC}_{6} \mathrm{H}_{5}$ from the fixed-charge phenacyl sulfonium ion peptide derivatives are shown in Scheme 4. Pathway 1 of Scheme 4 involves direct proton transfer by an intramolecular nucleophile $(\mathrm{Nu})$, such as the basic side chains of arginine or lysine, the $\mathrm{N}$-terminal amino group, or a backbone amide carbonyl group, resulting in elimination of the neutral to yield a 3-amino-1butenoic acid (vinyl glycine) amino acid derivative, with a residue mass of $83 \mathrm{Da}$. Alternatively, the fragmentation may be directed by a nucleophilic attack mechanism (Pathway 2 of Scheme 4), whereby an adjacent amide carbonyl attacks the side chain to facilitate the neutral loss. Pathway 2 of Scheme 4 shows this process occurring via nucleophilic attack by the amide carbonyl on the N-terminal side of the methionine sulfonium ion derivative, resulting in a 6-membered cyclic product. However, nucleophilic attack by the amide carbonyl on the C-terminal side of the methionine sulfonium ion derivative, resulting in a 5-membered cyclic product may also be considered. A recent MS/MS and molecular orbital study examining pathways for the loss of methanesulfenic acid from methionine sulfoxide containing peptides has indicated that both of these processes have similar transition state barriers ${ }^{\circ}[56]$.

Intramolecular transfer of an acidic proton present in either the precursor ion (Pathway 1), or in the product ion formed following methionine side chain cleavage (Pathway 2a or $2 \mathrm{~b}$ ) would result in "mobilization" of 

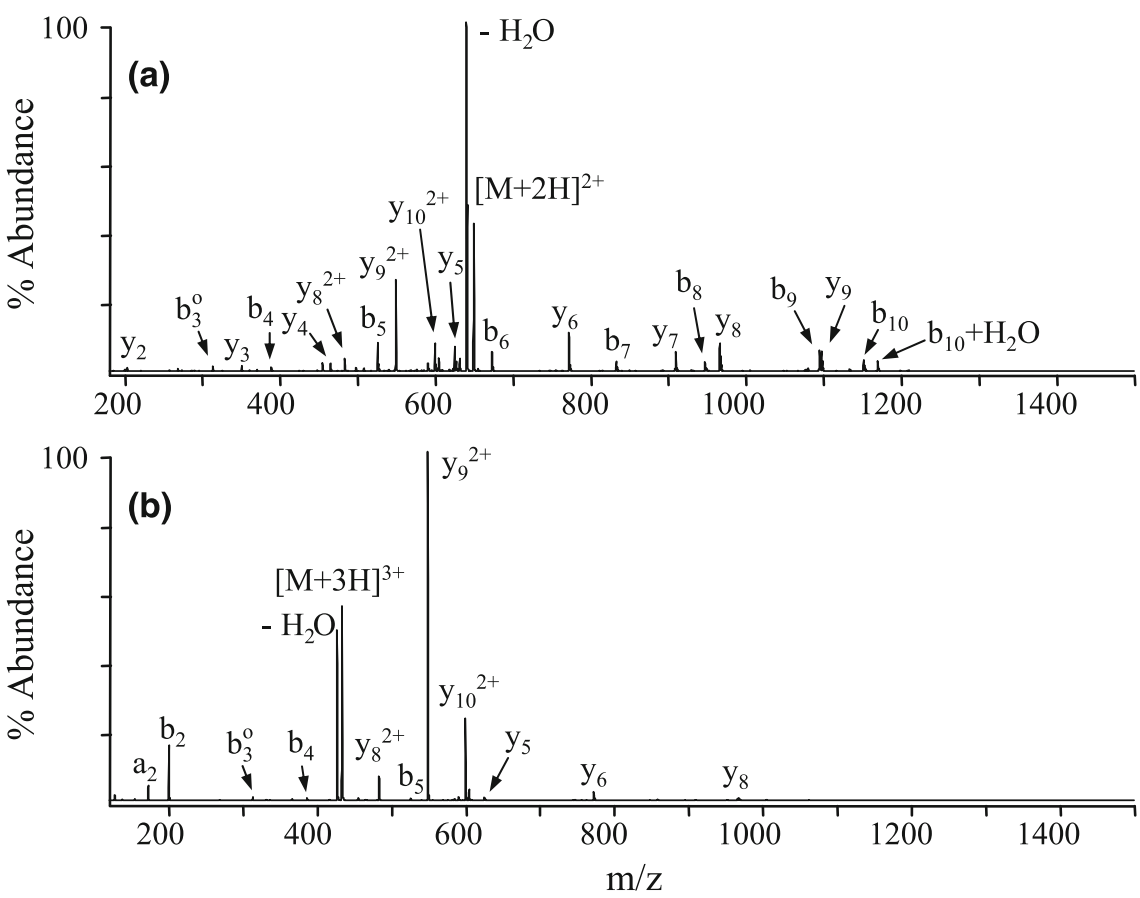

Figure 4. Analysis of VTMGHFC(S-carboxyamidomethyl)NFGK by quadrupole ion trap mass spectrometry. (a) CID MS/MS product ion spectrum of the $[\mathrm{M}+2 \mathrm{H}]^{2+}$ ion. (b) CID MS/MS product ion spectrum of the $[\mathrm{M}+3 \mathrm{H}]^{3+}$ ion.

this proton, thereby allowing it to be involved in subsequent fragmentation reactions according to the mobile proton model developed for rationalizing the fragmentation ${ }^{\circ}{ }^{\circ}$ protonated $^{\circ}$ peptide ${ }^{\circ}$ ions ${ }^{\circ}[51-56] .{ }^{\circ}$ Note that if the reaction proceeds via Pathway 2 of Scheme 4, the amide bond incorporated into the cyclic product would not be amenable to subsequent cleavage. However, ring opening of the cyclic product via intramolecular transfer (Pathway 2a) would yield the acyclic vinyl glycine amino acid derivative, thereby allowing subsequent fragmentation of the product ion to occur on both $\mathrm{N}$ - and C-terminal sides of the newly formed amino acid residue.

Given that the sulfonium ion derivatized peptide ions were observed to fragment almost exclusively via the neutral loss of $\mathrm{CH}_{3} \mathrm{SCH}_{2} \mathrm{COC}_{6} \mathrm{H}_{5}$ to form a charged product ion, a further stage of tandem mass spectrometry $\left(\mathrm{MS}^{3}\right)$ was employed, to generate additional structural information to allow identification of the peptide by sequence analysis, and to obtain evidence for the fragmentation mechanism. The spectra obtained following CID MS ${ }^{3}$ of each of the neutral loss ${ }^{\circ}$ product ${ }^{\circ}$ ions ${ }^{\circ}$ shown ${ }^{\circ}{ }^{\circ}{ }^{\circ}$ Figures $^{\circ} 1^{\circ}$ and ${ }^{\circ} 3^{\circ}$ above ${ }^{\circ}$ are shown $^{\circ}$ in $^{\circ}$ Figures $^{\circ} 5^{\circ}$ and $^{\circ} 6 .^{\circ} \mathrm{MS}^{3}$ of these ions, and indeed all the $\left[\mathrm{M}+\mathrm{nH}-\mathrm{CH}_{3} \mathrm{SAP}\right]^{(\mathrm{n}+1)+}$ product ions formed by neutral loss from the sulfonium ion fixed-charge peptide ions studied to date, resulted in the formation of $b$ - and y-type products ensuing from dissociations along the peptide backbone, similar to those observed by MS/MS of the unmodified peptide $\left[\mathrm{M}^{\circ}+{ }^{\circ} \mathrm{nH}\right]^{\mathrm{n}+{ }^{\circ}}$ precursor ${ }^{\circ}$ ions ${ }^{\circ}$ (Figures ${ }^{\circ}{ }^{\circ}$ and $\left.{ }^{\circ} 4\right) .{ }^{\circ}$ In ${ }^{\circ}$ most cases, cleavage of the amide bonds on either side of the proposed vinyl glycine residue formed by loss of the sulfonium ion side chain was observed following $\mathrm{MS}^{3}$, suggesting that the fragmenting species does contain an acyclic vinyl glycine residue, formed either by Pathway 1 of Scheme 4 or by ring opening of the cyclic product formed by Pathway $2 \mathrm{a}$ of Scheme 4.

\section{Energy Resolved CID MS/MS in a Quadrupole- Time-of-Flight Mass Spectrometer}

The dissociation reactions of the methionine side chain fixed charge sulfonium ion peptide derivatives described above have been further examined by energy resolved CID in a quadrupole-time-of-flight (Q-TOF) mass spectrometer. The energy resolved CID breakdown and appearance curves for the doubly charged sulfonium ion derivative of GAILMGAILK are shown

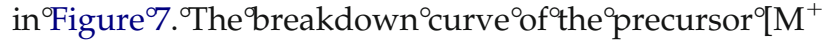
$+\mathrm{H}]^{2+}$ ion, the appearance/breakdown curve of the initial neutral loss product ion $\left(-\mathrm{CH}_{3} \mathrm{SAP}\right)$, as well as the appearance curves of the individual product ions and that of the summed product ion abundances (sum of $^{\circ}$ product ${ }^{\circ}$ ions $)^{\circ}$ are $^{\circ}$ indicated ${ }^{\circ}$ in $^{\circ}$ Figure $^{\circ} 7 \mathrm{a}^{\circ} .^{\circ} \mathrm{It}^{\circ} \mathrm{can}^{\circ}$ be seen that there is essentially no overlap between the breakdown of the $\left[\mathrm{M}^{+}+\mathrm{H}\right]^{2+}$ ion and the appearance of the individual product ions, indicating that these ions are not formed directly from the initial precursor. Rather, these ions are formed from the initial neutral loss product ion $\left(-\mathrm{CH}_{3} \mathrm{SAP}\right)$. Given that there was essentially no overlap in the collision energies required 

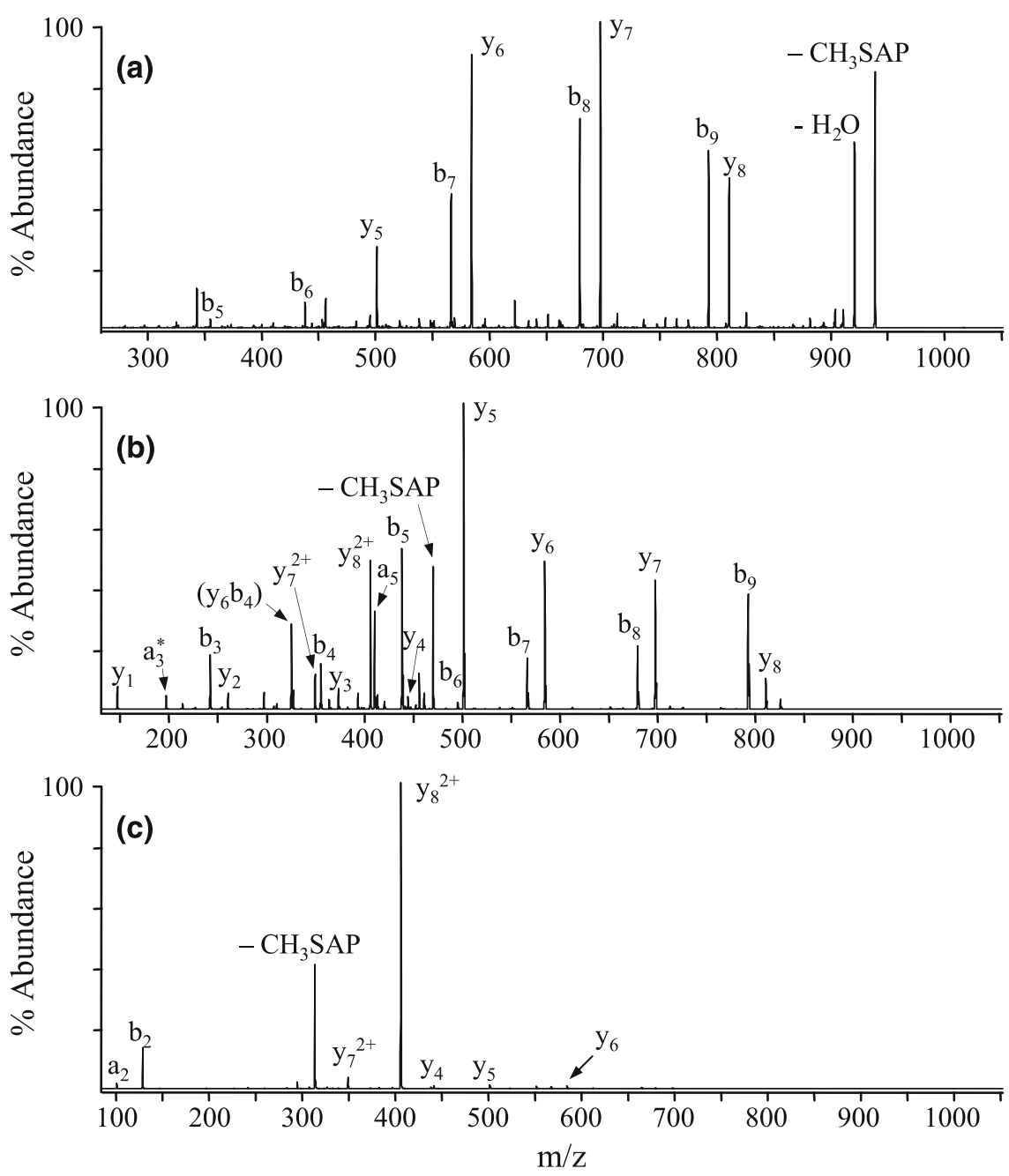

Figure 5. Multistage tandem mass spectrometry $\left(\mathrm{MS}^{3}\right)$ analysis of the neutral loss product ions obtained from the methionine side chain phenacyl sulfonium ion derivative of GAILMGAILK in Figure ${ }^{\circ} 1 .^{\circ}\left(\mathbf{a}^{\circ} \mathrm{CID}^{\circ} \mathrm{MS}^{3^{\circ}}\right.$ product ${ }^{\circ}$ ion ${ }^{\circ}$ spectrum ${ }^{\circ}$ of ${ }^{\circ}$ the ${ }^{\circ}\left[\mathrm{M}^{+}-{ }^{\circ} \mathrm{CH}_{3} \mathrm{SAP}\right]^{+{ }^{\circ}}$ product ${ }^{\circ}$ ion ${ }^{\circ}$ from ${ }^{\circ}$ Figure ${ }^{\circ} 1 \mathrm{a} .{ }^{\circ}(\mathbf{b})$ $\mathrm{CID} \mathrm{MS}^{3}$ product ion spectrum of the $\left[\mathrm{M}^{+}+\mathrm{H}-\mathrm{CH}_{3} \mathrm{SAP}_{0}\right]^{2+}$ product ion from ${ }^{\circ}$ Figure $1 \mathrm{~b} .{ }^{9}(\mathrm{c})^{\circ} \mathrm{CID}^{\circ} \mathrm{MS}^{3}$ product ion spectrum of the $\left[\mathrm{M}^{+}+2 \mathrm{H}-\mathrm{CH}_{3} \mathrm{SAP}\right]^{3+}{ }^{\circ}$ product $^{\circ}$ ion ${ }^{\circ}$ from ${ }^{\circ}$ Figure $^{\circ} 1 \mathrm{c}$.

for $>90 \%$ reduction of the fixed charge containing precursor ion abundance and the formation of second generation product ions from the initial side chain neutral loss product ion, automated data-dependent acquisition methods could be readily developed, whereby "low" energy quadrupole CID conditions are employed for the identification of derivatized peptide ions by the selective formation and detection of an neutral loss product ion, followed by "high" energy "pseudo MS ${ }^{3 "}$ CID conditions to obtain further structural information regarding the peptide sequence.

Representative product ion spectra taken under collision energies sufficient to obtain $70-90 \%$ reduction of the precursor ion $(12 \mathrm{eV})$ and $70-90 \%$ reduction of the initial neutral loss product ion $(22 \mathrm{eV})$ abundances are shown in ${ }^{\circ}$ Figure $7 b^{\circ}{ }^{\circ} d^{\circ} c$, respectively. The ${ }^{\text {p product }}$ ion spectra observed under these "low" and "high" energy quadrupole CID conditions, respectively, are essentially identical to those observed by quadrupole ion trap mass spectrometry MS/MS and $\mathrm{MS}^{3}$ experiments, indicating that the time frame (millisecond versus microsecond time scales for the ion trap and quadrupole experiments, respectively) and mode of ion activation had no appreciable effect on the fragmentation behavior. Indeed, all of the peptides examined under these "low" and "high" energy quadrupole CID conditions exhibited very similar product ion spectra compared to the equivalent ion trap derived MS/MS and $\mathrm{MS}^{3}$ spectra.

\section{Identification of Methionine Containing Peptides in a Triple Quadrupole Mass Spectrometer by Neutral Loss Scan Code CID MS/MS of Their Sulfonium Ion Fixed-Charge Derivatives}

In order to demonstrate the selectivity of the fixed charge derivatization and tandem mass spectrometry approach for the identification of sulfonium ion con- 

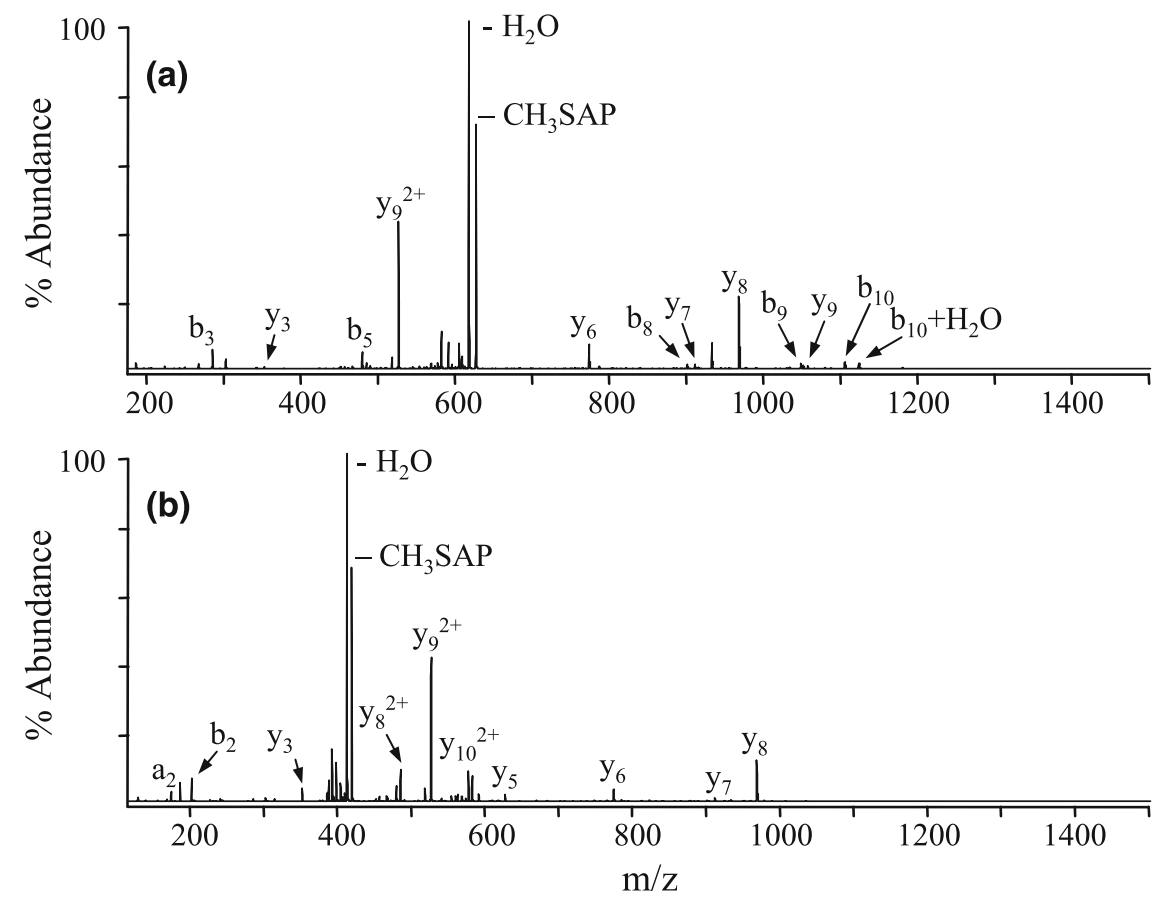

Figure 6. Multistage tandem mass spectrometry $\left(\mathrm{MS}^{3}\right)$ analysis of the neutral loss product ions obtained from the methionine side chain phenacyl sulfonium ion derivative of VTMGHFC(Scarboxyamidomethyl)NFGK ${ }^{\circ}$ in $^{\circ}$ Figure $^{\circ} 3 .^{\circ}\left(a^{\circ}\right)^{\circ} \mathrm{CID}^{\circ} \mathrm{MS}^{3^{\circ}}$ product $^{\circ}$ ion $^{\circ}$ spectrum ${ }^{\circ}$ of ${ }^{\circ}$ the ${ }^{\circ}\left[\mathrm{M}^{+}+{ }^{\circ} \mathrm{H}^{\circ}-\right.$ $\left.\mathrm{CH}_{3} \mathrm{SAP}\right]^{2+}{ }^{\circ}$ product $^{\circ}$ ion $^{\circ}$ from $^{\circ}$ Figure $^{\circ} 3 \mathrm{~b}^{\circ} .^{\circ}(\mathbf{b})^{\circ} \mathrm{CID}^{\circ} \mathrm{MS}^{3^{\circ}}$ product $^{\circ}$ ion $^{\circ}$ spectrum ${ }^{\circ}$ of the $^{\circ}\left[\mathrm{M}^{+}+{ }^{\circ} 2 \mathrm{H}^{\circ}-\right.$ $\left.\mathrm{CH}_{3} \mathrm{SAP}\right]^{3+}{ }^{\circ}$ product $^{\circ}$ ion ${ }^{\circ}$ from ${ }^{\circ}$ Figure $3 \mathrm{c}$.

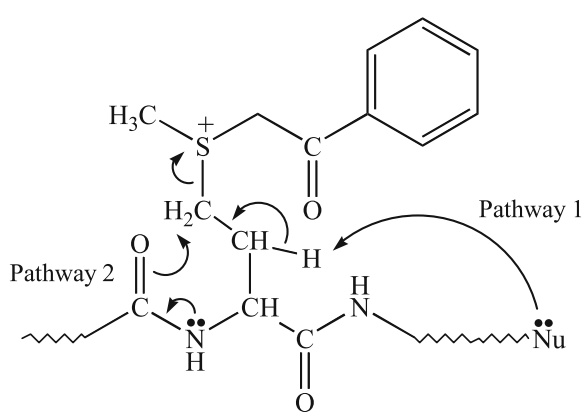

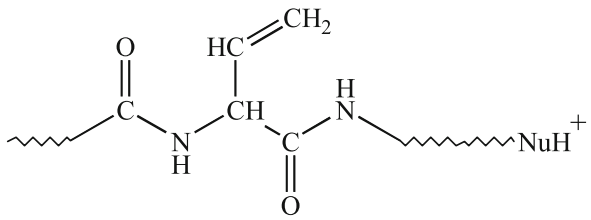
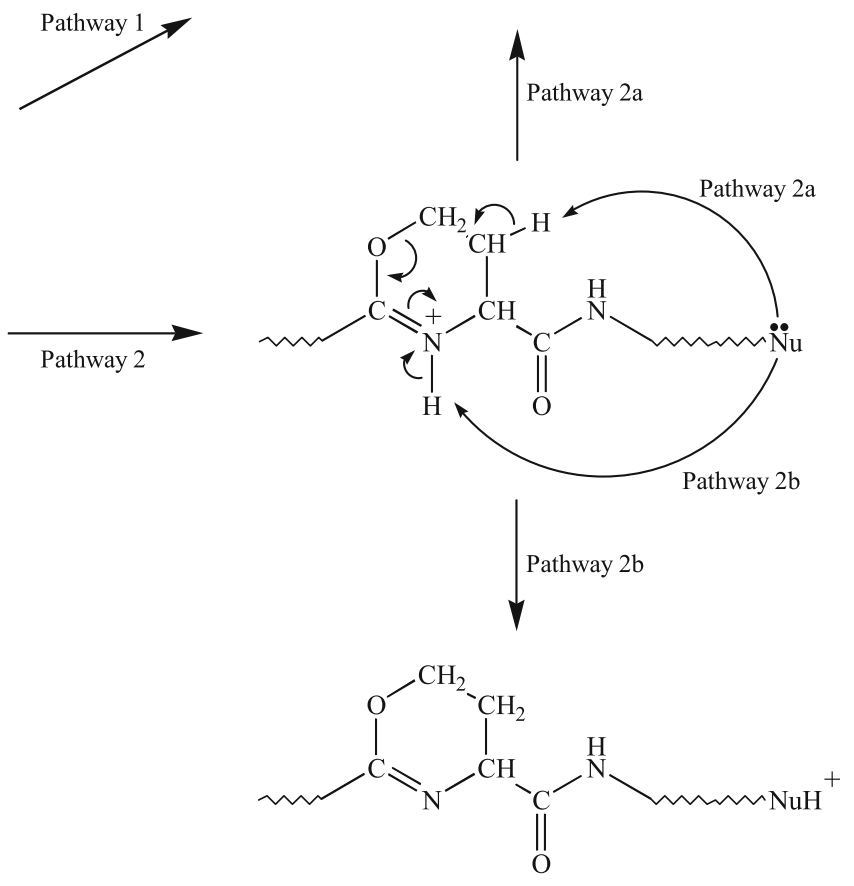

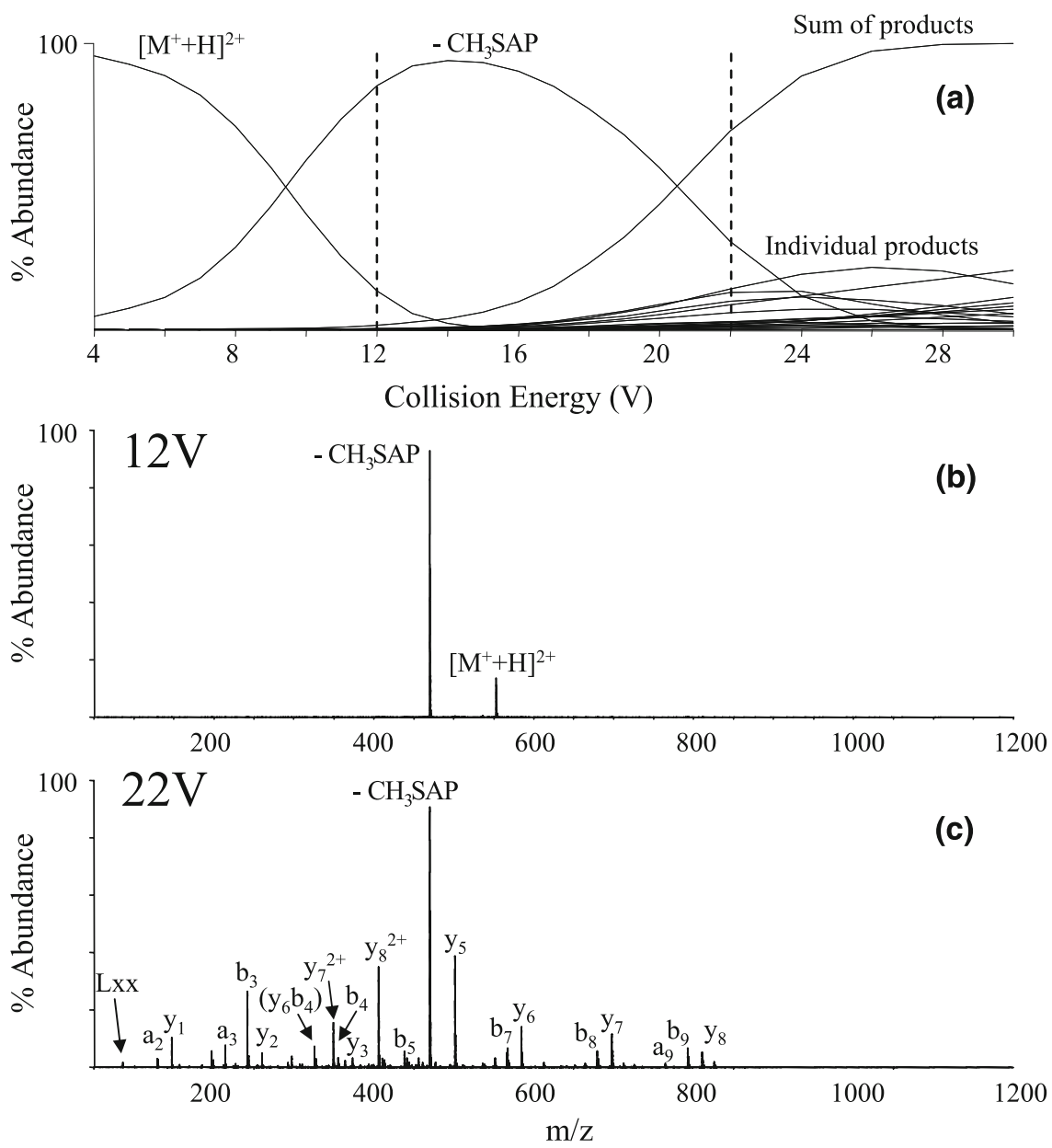

Figure 7. CID MS/MS of the doubly charged methionine side chain phenacyl sulfonium ion fixed-charge derivative of GAILMGAILK in a quadrupole time-of-flight mass spectrometer. (a) Energy resolved breakdown curve for the $\left[\mathrm{M}^{+}+\mathrm{H}\right]^{2+}$ ion. (b) CID MS/MS product ion spectra of the $\left[\mathrm{M}^{+}+\mathrm{H}\right]^{2+}$ ion obtained at a collision energy (laboratory frame) of $12 \mathrm{~V}$. (c) CID MS/MS product ion spectra of the $\left[\mathrm{M}^{+}+\mathrm{H}\right]^{2+}$ ion obtained at a collision energy (laboratory frame) of $22 \mathrm{~V}$.

taining peptides, $100 \mathrm{pmol}$ of the $66 \mathrm{kDa}$ protein bovine serum albumin was reduced and S-carboxyamidomethylated under basic $\mathrm{pH}$ conditions, then subjected to proteolytic digestion using trypsin. The resultant peptide mixture then reacted under acidic conditions with phenacylbromide to yield the side chain sulfonium ion derivatives of methionine containing peptides within the mixture. Ten pmol of this reduced, S-carboxyamidomethylated and sulfonium ion derivatized tryptic peptide mixture was then subjected to on-line capillary RP-HPLC ESI MS using a triple quadrupole mass spectrometer. The total ion current trace obtained from $^{\circ}$ this $^{\circ}$ analysis ${ }^{\circ}$ is $^{\circ}$ shown $^{\circ}$ in $^{\circ}$ Figure $^{\circ} 8$ a. ${ }^{\circ}$ Several ${ }^{\circ}$ hundred multiply charged ions, corresponding to approximately 100 peptides, were observed by analysis of the individual spectra acquired throughout the chromatographic separation. In the absence of any a priori knowledge regarding the protein sequence however, identification of the sulfonium ion derivatized peptide ions from these mass spectra would not be readily achieved.
Analysis of the same peptide mixture was carried out by on-line capillary RP-HPLC and using a neutral loss scan mode CID MS/MS experiment, to reveal those peptides giving rise to the loss of $83 \mathrm{Th}$, i.e., the loss of $\mathrm{CH}_{3} \mathrm{SCH}_{2} \mathrm{COC}_{6} \mathrm{H}_{5}, 166$ Da from doubly charged methionine side chain sulfonium ion containing precursor ions. The total ion current obtained from this experiment ${ }^{\circ}{ }^{\circ}{ }^{\circ}$ hown ${ }^{\circ}{ }^{\circ}{ }^{\circ}$ igure ${ }^{\circ} 9$ a. ${ }^{\circ}$ Four ${ }^{\circ}$ peaks ${ }^{\circ}$ were ${ }^{\circ}$ observed. The mass spectra of the most abundant and least abundant ${ }^{\circ}$ of $^{\circ}$ these $^{\circ}$ four $^{\circ}$ peaks $^{\circ}$ are $^{\circ}$ shown $^{\circ}$ in $^{\circ}$ Figure $^{\circ} 9 \mathrm{~b}$ and $c$. The masses of the major ions present in these four peaks were found to closely correspond to those calculated for tryptic peptides containing each of the four methionine residues within the bovine serum albumin amino ${ }^{\circ}$ acid $^{\circ}$ sequence. The $^{\circ}$ mass $^{\circ}$ spectra ${ }^{\circ}$ hown in Figure $8 \mathrm{~b}^{\circ}$ and ${ }^{\circ} \mathrm{C}$, ${ }^{\circ}$ corresponding ${ }^{\circ}$ to ${ }^{\circ}$ the ${ }^{\circ}$ two ${ }^{\circ}$ regions ${ }^{\circ}$ of ${ }^{\circ}$ the ${ }^{\circ}$ total ion current chromatogram shown by arrows in the MS experiment, indicate that the ions detected in the neutral ${ }^{\circ} \operatorname{loss}^{\circ}$ scan $^{\circ}$ mode ${ }^{\circ}$ experiment ${ }^{\circ}$ in ${ }^{\circ}$ Figure ${ }^{\circ} 9 b^{\circ}$ and ${ }^{\circ} \mathrm{c}^{\circ}$ are present at relatively low abundance (the ion at $m / z 799.4$ in $^{\circ}$ Figure $^{\circ} 9 \mathrm{~b}^{\circ}$ is $^{\circ}$ only $^{\circ}$ the ${ }^{\circ}$ eighth $^{\circ}$ most $^{\circ}$ abundant ${ }^{\circ}$ ion $^{\circ}$ in 

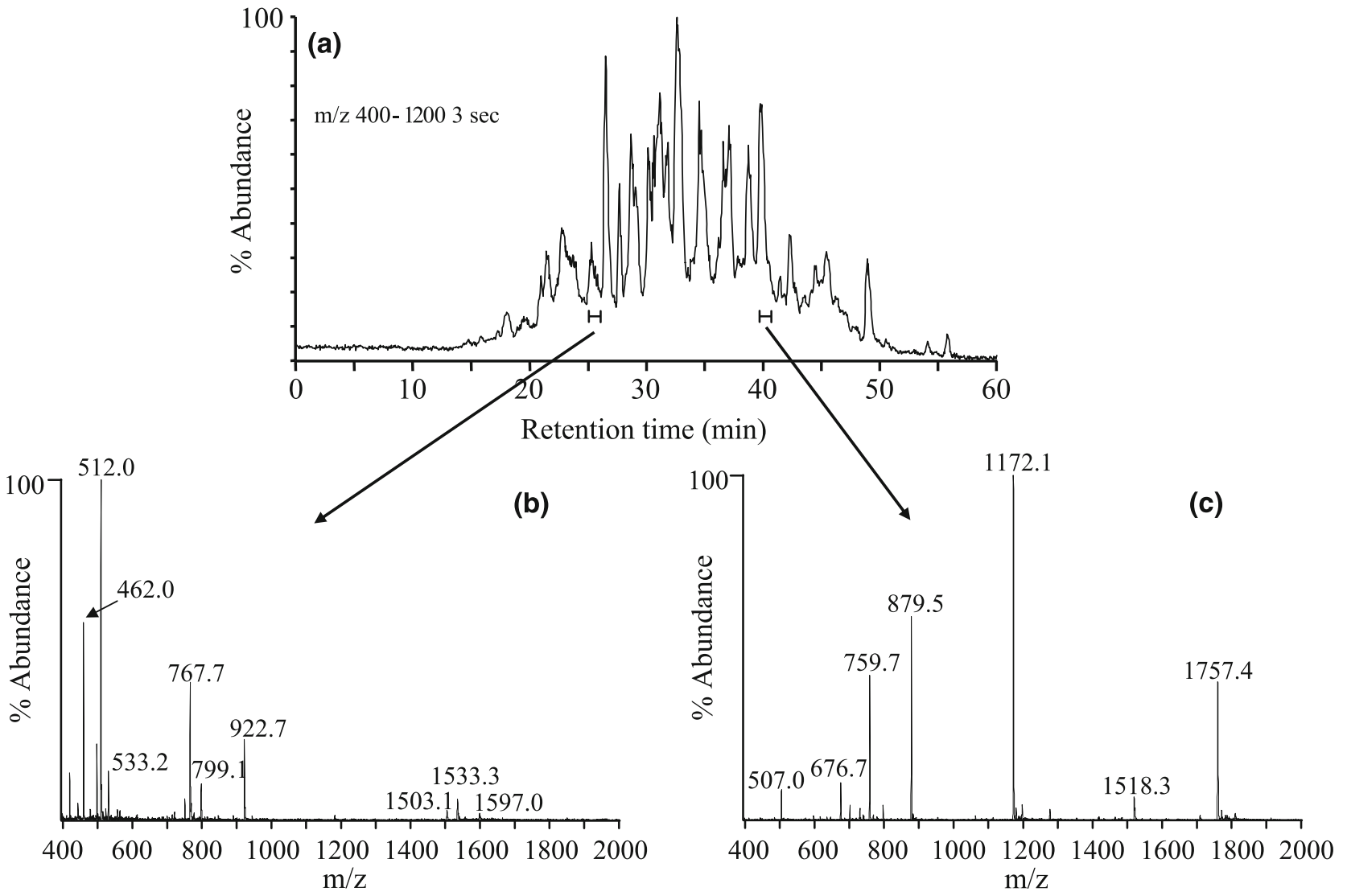

Figure 8. (a) Total ion current trace from a $200 \mu \mathrm{m}$ i.d. capillary RP-HPLC-triple quadrupole MS analysis of $10 \mathrm{pmol}$ of a reduced and S-carboxyamidomethylated tryptic digest of bovine serum albumin, following sulfonium ion derivatization with phenacylbromide. (b) and (c) Mass spectra of

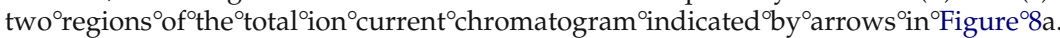

Figure $8 \mathrm{~b},{ }^{\circ}$ and ${ }^{\circ}$ the ${ }^{\circ}$ ion $^{\circ}$ at $^{\circ} \mathrm{m} / \mathrm{z} 759.8^{\circ}$ in $^{\circ}$ Figure $^{\circ}{ }^{\circ} \mathrm{c}^{\circ}$ is ${ }^{\circ}$ only the ${ }^{\circ}$ third ${ }^{\circ} \operatorname{most}^{\circ}$ abundant ${ }^{\circ}$ ion ${ }^{\circ}$ in $^{\circ}$ Figure $^{\circ} 9 \mathrm{c}$ ).

\section{Differential Quantitative Analysis by Neutral Loss Scan Mode CID MS/MS of Stable Isotope Labeled Fixed-Charge Containing Peptide Derivatives in a Triple Quadrupole Mass Spectrometer}

The potential for extending the sulfonium ion derivatization approach toward the quantitation of differential protein expression between two peptide samples of interest has been examined by differential stable isotope labeling and neutral loss scan mode MS/MS in a triple quadrupole mass spectrometer. The synthetic peptide GAIMGAILR was derivatized with either a "light" phenacylbromide reagent containing only naturally abundant isotopes $\left({ }^{1} \mathrm{H}_{5}\right.$-phenacylbromide) or a "heavy" phenacylbromide reagent containing five deuterium isotopes $\left(2^{\prime}, 3^{\prime}, 4^{\prime}, 5^{\prime}, 6^{\prime}-{ }^{2} \mathrm{H}_{5}\right.$-phenacylbromide). A nominal $1.0 \mathrm{pmol} / \mu \mathrm{L}: 1.0 \mathrm{pmol} / \mu \mathrm{L}$ mixture of the two derivatized samples was then subjected to MS and neutral loss scan mode MS/MS analysis. By measurement of the peak intensities from the intact precursor ions $^{\circ}$ observed $^{\circ}$ in $^{\circ}$ the ${ }^{\circ}$ mass spectrum ${ }^{\circ}$ shown $^{\circ}$ in ${ }^{\circ}$ Figure $10 a^{\circ}$ a ratio of 1.04:1 can be determined for the doubly $(\mathrm{m} / \mathrm{z} 567.2$ and 569.7) charged states of the peptides, and a ratio of $1.06: 1$ for the triply $(\mathrm{m} / \mathrm{z} 378.4$ and 380.1) charged states of the peptides. A ten times expanded region of the mass spectrum between $\mathrm{m} / \mathrm{z} 700-800$ shows the level of chemical noise associated with this data acquisition. In comparison, the neutral loss scan mode MS/MS spectra of the same mixture (neutral losses of 83 and $85.5 \mathrm{Th}$, respectively. for the doubly charged precursor ions, and neutral losses of 55.3 and $57 \mathrm{Th}$, respectively, for the triply charged precursor ions) ${ }^{\circ}$ are $^{\circ}$ shown ${ }^{\circ}$ in ${ }^{\circ}$ Figure ${ }^{\circ} 10 \mathrm{~b} .{ }^{\circ}$ Again, the $m / z$ 700-800 regions for each spectrum have been expanded ten times to indicate the level of chemical noise. While the observed ratios for ${ }^{\circ}$ the ${ }^{\circ} \mathrm{MS} / \mathrm{MS}^{\circ}$ neutral ${ }^{\circ}$ loss scan ${ }^{\circ}$ mode ion ${ }^{\circ}$ bundances in Figure $10 \mathrm{~b}^{\circ}$ are ${ }^{\circ}$ essentially ${ }^{\circ}$ dentical to those ${ }^{\circ}$ observed $^{\circ}$ for $^{\circ}$ the $^{\circ} \mathrm{MS}^{\circ}$ ion ${ }^{\circ}$ abundances ${ }^{\circ}$ in Figure $10 a,{ }^{\circ}$ the ${ }^{\circ}$ level of chemical noise is reduced by at least two orders of magnitude compared with that observed in the mass spectrum. Indeed, with the exception of electronic noise, characterized by single data point noise "spikes", the neutral loss MS/MS spectra showed a complete absence of nonspecific chemical noise along the baseline. This is further demonstrated by the neutral loss scan mode MS/MS data acquired from a nominal 1 $\mathrm{pmol} / \mu \mathrm{L}: 0.1 \mathrm{pmol} / \mu \mathrm{L}$ mixture of the light and heavy 


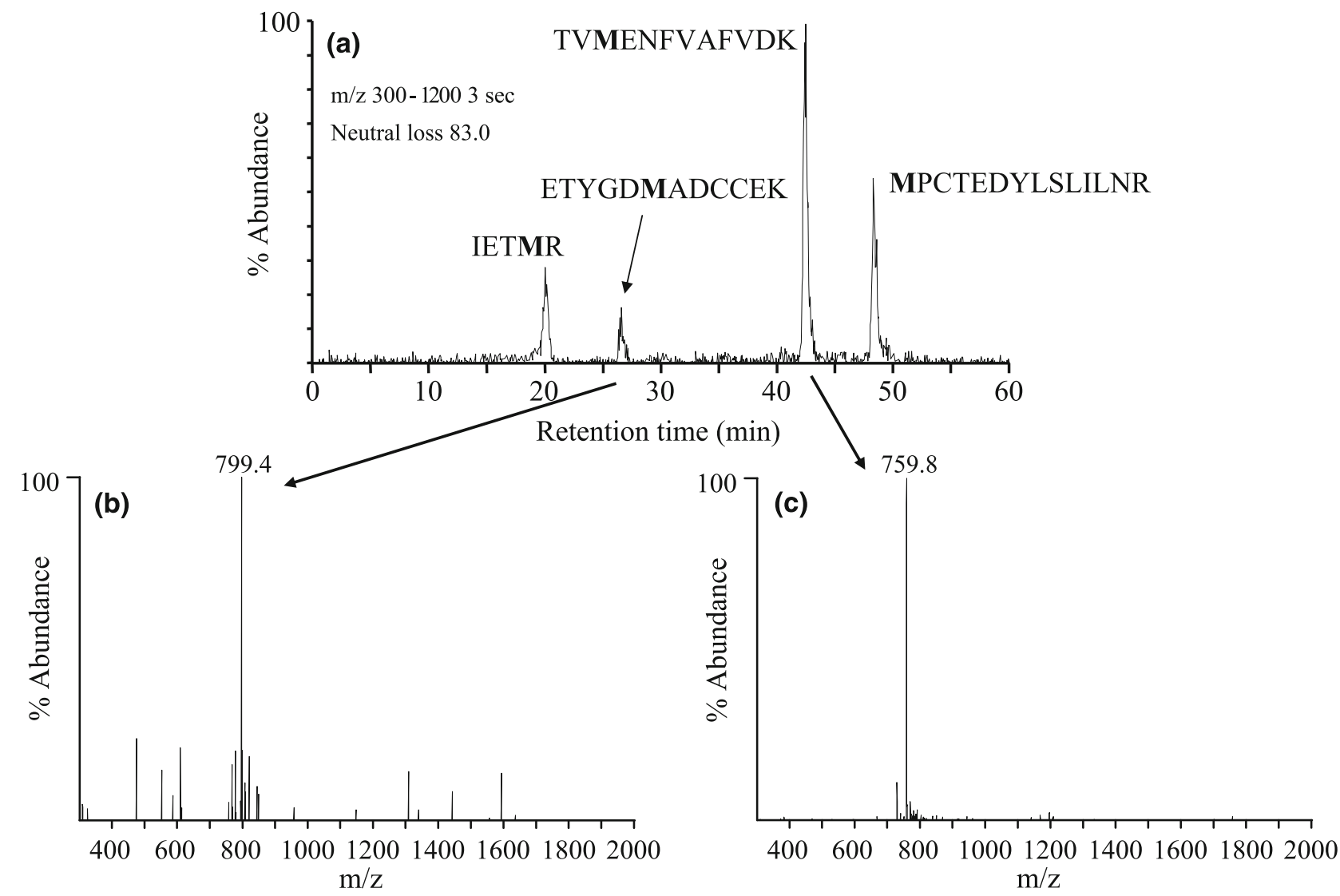

Figure 9. (a) Total ion current trace from a $200 \mu \mathrm{m}$ i.d. capillary RP-HPLC-triple quadrupole neutral loss scan mode CID MS/MS analysis of $10 \mathrm{pmol}$ of a reduced and S-carboxyamidomethylated tryptic digest of bovine serum albumin, following sulfonium ion derivatization with phenacylbromide. (b) and (c) Neutral loss scan mode mass spectra of two regions of the total ion current chromatogram indicated ${ }^{\circ}$ y $^{\circ}$ arrows $^{\circ}$ in $^{\circ}$ Figure $^{\circ} 9$ a.

labeledGAILMGAILR peptide(Figure 11 ). The ${ }^{9}$ ratios $^{\circ}$ of the ions obtained by this neutral loss scan mode MS/MS experiment were determined to be $9.45: 1$ and 10.83:1 for the doubly and triply charged forms of the peptides, respectively, and were similar to that observed by MS, where ratios of 9.72:1 and 10.12:1, respectively, were obtained (data not shown). Once again, the level of chemical noise in the neutral loss scan mode experiment was found to be at least two orders of magnitude lower compared with that observed in the mass spectrum. For a range of neutral loss scan mode MS/MS experiments performed to date, with nominal ratios of 0.1:1, 0.2:1.0, 0.5:1.0, 1.0:1.0, 1.0:0.5, 1.0:0.2, and 1.0:0.1, experimental errors were all within $10 \%$ of the expected values.

A particular advantage of the MS/MS method for differential quantitative analysis described here, over those involving analysis by MS peak abundances alone, is that both ions (i.e., light and heavy labeled forms) are not required to be present in order for detection of one of the pairs, and its origin (i.e., from the "light" or "heavy" sample), to be obtained. Thus, quantitation of peptide ions that are significantly over- or underexpressed compared with a control may still be achieved. Also, given that a common product is formed by neutral loss from both "light" and "heavy" labeled ions, either product may be selected for further structural analysis by "high" energy pseudo CID or $\mathrm{MS}^{3}$.

One pmol each of the light and heavy derivatized GAILMGAILR peptides were then combined and subjected to capillary RP-HPLC MS analysis. The resultant total ion current trace for this experiment is shown in Figure $^{\circ} 12 \mathrm{a} .{ }^{\circ}$ By $^{\circ}$ measurement ${ }^{\circ}$ of $^{\circ}$ the ${ }^{\circ}$ peak $^{\circ}$ intensities from ${ }^{\circ}$ the ${ }^{\circ}$ mass $^{\circ}$ spectrum ${ }^{\circ}$ shown ${ }^{\circ}{ }^{\circ}{ }^{\circ}$ Figure $12 b$, obtained by summing the individual spectra acquired across the region of the chromatogram spanning 40.7 to $43.0 \mathrm{~min}$, abundance ratios of 1.06:1 and 1.04:1 were obtained from the doubly and triply charged states of the peptide, respectively. Neutral loss scan mode CID MS/MS analysis of the same mixture, whereby neutral loss scans of 83 and 85.5 Th (for the doubly charged precursors) and 55.3 and 57 Th (for the triply charged precursors), were obtained in successive scans throughout the chromatographic $^{\circ}$ separation $^{\circ}\left(\text { Figure }^{\circ} 12 \mathrm{c}\right)^{\circ}$ and $^{\circ}$ then summed $^{\circ}$ for $^{\circ}$ display $^{\circ}\left(\right.$ Figure $\left.^{\circ} 12 \mathrm{~d}\right),{ }^{\circ}$ yielded $^{\circ}$ an $^{\circ}$ average abundance ratio essentially identical to that obtained by MS. Once again, the level of chemical noise in the neutral loss scan mode MS/MS spectrum was significantly reduced compared with that in the MS derived data, indicating that the MS/MS approach may provide 

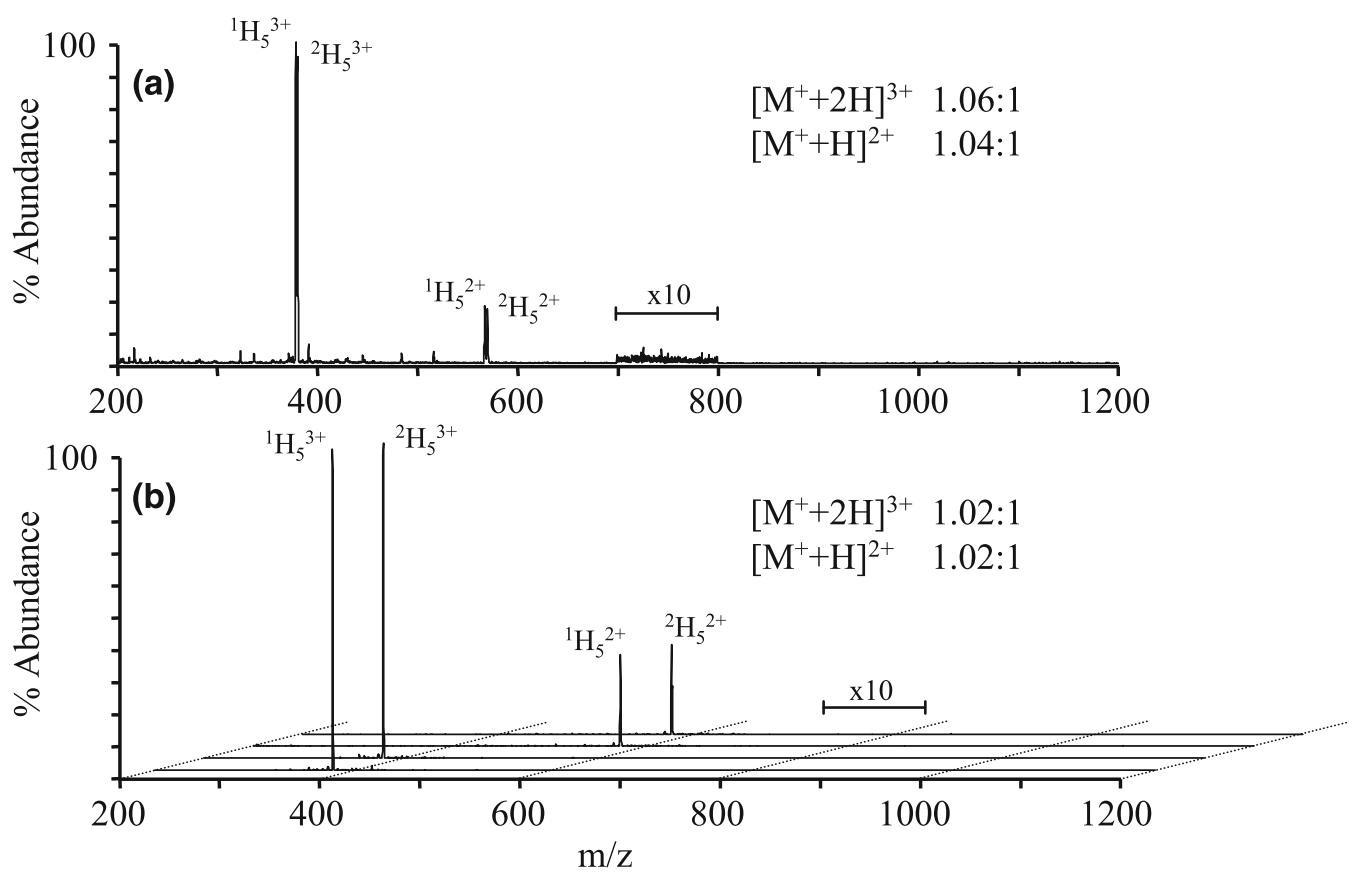

Figure 10. (a) Triple quadrupole mass spectrum of a $1.0: 1.0 \mathrm{pmol} / \mu \mathrm{L}$ mixture of ${ }^{1} \mathrm{H}_{5^{-}}$and ${ }^{2} \mathrm{H}_{5}$-containing methionine side chain phenacyl sulfonium ion fixed charge derivative of GAILMGAILR. (b) Neutral loss scan mode CID MS/MS spectra (neutral losses of 83.0 and 85.5 Th for doubly charged ions and 5.3 and 57.0 Th for triply charged ions) from the ${ }^{1} \mathrm{H}_{5}$ - and ${ }^{2} \mathrm{H}_{5}$-containing derivatives.

significantly greater sensitivity than MS methods for differential quantitative analysis. The approach could also by readily applied to the "absolute" quantitative analysis of protein expression, in an analogous manner to recent reports whereby a known quantity of an isotopically encoded peptide of interest is "spiked" into $a^{\circ}$ sample $^{\circ}$ of $^{\circ}$ interest ${ }^{\circ}$ as $^{\circ}{ }^{\circ}$ an internal ${ }^{\circ}$ standard $^{\circ}[101]$.

Less than $10 \%$ separation of the ${ }^{1} \mathrm{H}_{5}$ - and ${ }^{2} \mathrm{H}_{5}$ forms of the fixed charge sulfonium ion derivatives across the chromatographic $^{\circ}$ peaks $^{\circ}$ in $^{\circ}$ Figure $^{\circ} 12^{\circ}$ was $^{\circ}$ observed, indicating that there is not a strong deuterium isotope effect on the chromatographic fractionation of these fixed charge derivatives. This is consistent with recent reports describing the factors controlling deuterium isotope $\mathrm{effects}^{\circ} \mathrm{on}^{\circ} \mathrm{chromatography}^{\circ}\left[35,{ }^{\circ} 36\right]^{\circ} .{ }^{\circ} \mathrm{In}^{\circ}$ future work, however, replacement of ${ }^{2} \mathrm{H}$ with ${ }^{13} \mathrm{C}$ within the "heavy" derivatization reagent will ensure that light and heavy isotopic variants coelute upon HPLC fractionation, thereby allowing more accurate quantitation without the need for signal averaging across an entire chromatographic peak. For future applications involving the analysis of methionine sulfonium ion containing peptides from complex biologically derived mixtures, the fixed charge derivatives could be pre-enriched by a range of methods prior to mass spectrometry analysis, including ${ }^{\circ}$ diagonal ${ }^{\circ} \mathrm{chromatography}[102]$, strong $^{\circ}$ cation exchange $\left[76,{ }^{\circ} 103\right],{ }^{\circ}{ }^{\circ}{ }^{\circ}$ solid $^{\circ}$ phase $^{\circ}$ capture $[77],{ }^{\circ}$ thereby simplifying the mixture complexity and minimizing the potential for $\mathrm{m} / \mathrm{z}$ overlap between unlabeled and labeled peptide ions. However, either of the two later

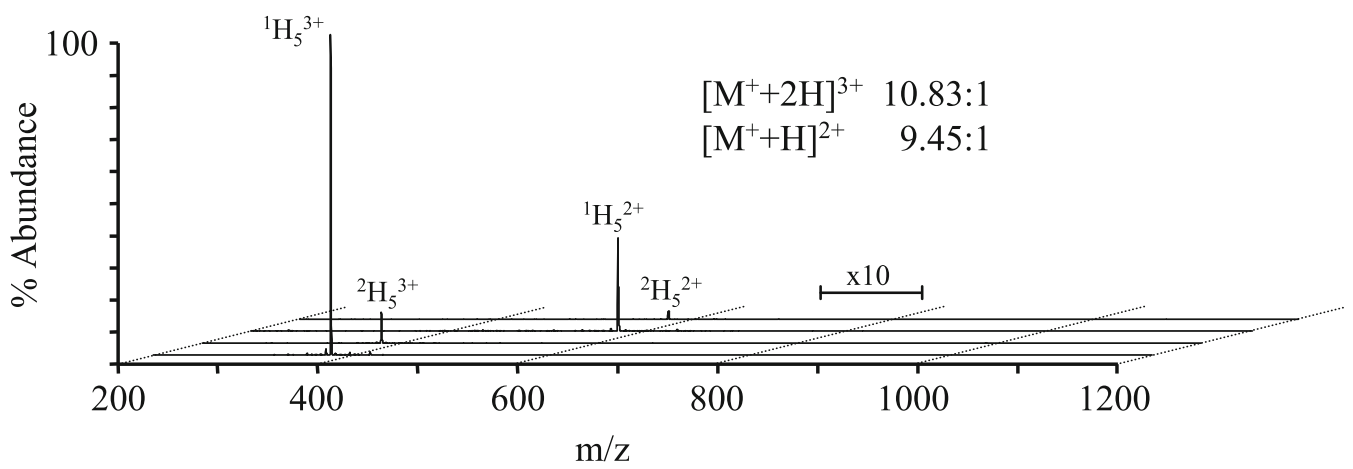

Figure 11. Triple quadrupole neutral loss scan mode CID MS/MS spectra (neutral losses of 83.0 and 85.5 Th for doubly charged ions and 5.3 and 57.0 Th for triply charged ions) from a 1.0:0.1 pmol/ $\mu \mathrm{L}$ mixture of ${ }^{1} \mathrm{H}_{5^{-}}$and ${ }^{2} \mathrm{H}_{5}$-containing methionine side chain phenacyl sulfonium ion fixed charge derivative of GAILMGAILR. 

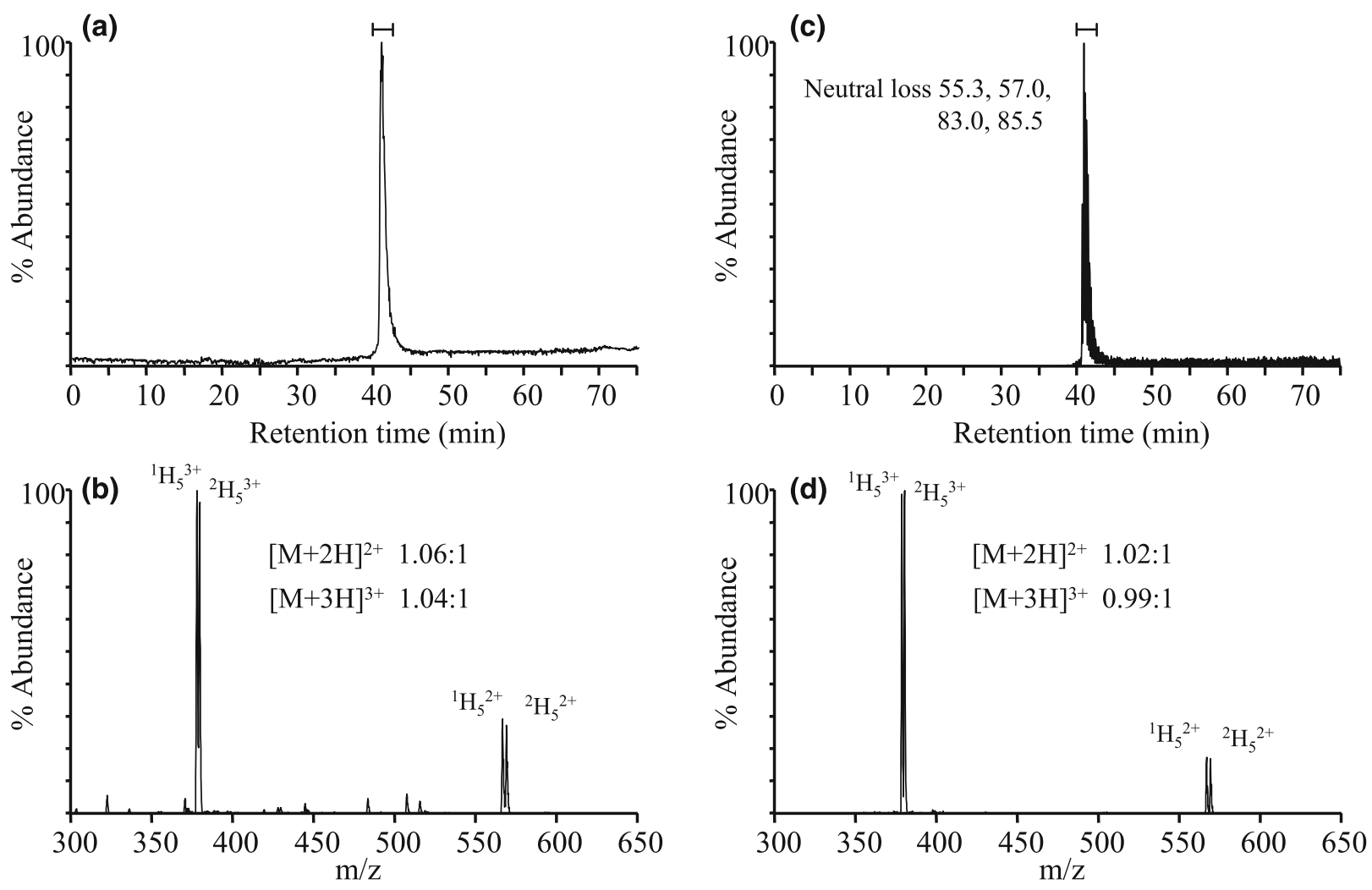

Figure 12. $75 \mu \mathrm{m}$ i.d. capillary RP-HPLC-MS analysis of a 1 pmol mixture of ${ }^{1} \mathrm{H}_{5}$ - and ${ }^{2} \mathrm{H}_{5}$-containing methionine side chain phenacyl sulfonium ion fixed charge derivatives of GAILMGAILR. (a) Total ion current trace obtained by MS analysis. (b) Summed mass spectrum of the 40.7 to 43.0 min region indicated in Panel (a). (c) Total ion current trace obtained by neutral loss scan mode MS/MS analysis (neutral losses of 83.0 and 85.5 Th for doubly charged ions and 5.3 and 57.0 Th for triply charged ions).

(d) Summed mass spectrum of the 40.7 to 43.0 min region indicated in Panel (c).

approaches is preferred because of the ability to obtain direct enrichment of labeled peptides without requirement for separate chromatographic analysis of both unmodified and modified samples.

\section{Conclusions}

This study describes a novel strategy for the selective identification of methionine containing peptides and proteins via the formation of side chain "fixed-charge" sulfonium ion derivatives. These sulfonium ions undergo exclusive loss of the derivatized methionine side chain upon CID MS/MS, with concomitant formation of a single characteristic product ion, independent of charge state or amino acid composition. Further structural interrogation of identified peptide ions is achieved by subjecting the characteristic MS/MS product ion to multistage MS/MS $\left(\mathrm{MS}^{3}\right)$ in a quadrupole ion trap mass spectrometer, or by energy resolved "pseudo" MS ${ }^{3}$ in a triple quadrupole mass spectrometer. While the side chain fixed charge derivatization approach has been demonstrated here for a specific amino acid (methionine) and derivatization reaction (sulfonium ions), in principle this approach should be readily applicable to other types of amino acid residues and derivatization reactions.

\section{Acknowledgments}

GER acknowledges the award of an Australian Research Council (ARC) post-doctoral fellowship.

\section{Supplementary Data}

Supplementary data associated with this article can be found, ${ }^{\circ}$ in $^{\circ}$ the $^{\circ}$ online ${ }^{\circ}$ version, ${ }^{\circ}$ at ${ }^{\circ}$ doi:10.1016/ j.jasms.2005.03.015.

\section{References}

1. Blackstock, W. P.; Weir, M. P. Proteomics: Quantitative and physical mapping of cellular proteins. Trends Biotechnol. 1999, $17,121-127$.

2. Mann, M.; Hendrickson, R. C.; Pandey, A. Analysis of proteins and proteomes by mass spectrometry. Annu. Rev. Biochem. 2001, 70, 437-473.

3. Aebersold, R.; Goodlett, D. R. Mass spectrometry in proteomics. Chem. Rev. 2001, 101, 269-295.

4. Hunt, D. F.; Yates, J. R.; Shabanowitz, J.; Winston S.; Hauer, C. R. Protein sequencing by tandem mass spectrometry. Proc. Natl. Acad. Sci. U.S.A. 1986, 83, 6233-6237.

5. Eng, J. K.; McCormack, A. L.; Yates, J. R. An approach to correlate tandem mass spectral data of peptides with amino acid sequences in a protein database. J. Am. Soc. Mass Spectrom. 1994, 5, 976-989. 
6. Mann, M.; Wilm, M. Error-tolerant identification of peptides in sequence databases by peptide sequence tags. Anal. Chem. 1994, 66, 4390-4399.

7. Spahr, C. S.; Susin, S. A.; Bures, E. J.; Robinson, J. H.; Davis, M. T.; McGinley, M. D.; Kroemer, G.; Patterson, S. D. Simplification of complex peptide mixtures for proteomic analysis: Reversible biotinylation of cysteinyl peptides. Electrophoresis. 2000, 21, 1635-1650.

8. Washburn, M. P.; Wolters, D.; Yates, J. R. Large-scale analysis of the yeast proteome by multidimensional protein identification technology. Nat. Biotechnol. 2001, 19, 242-247.

9. Spahr, C. S.; Davis, M. T.; McGinley, M. D.; Robinson, J. H.; Bures, E. J.; Beierle, J.; Mort, J.; Courchesne, P. L.; Chen, K.; Wahl, R. C.; Yu, W.; Luethy, R.; Patterson, S. D. Towards defining the urinary proteome using liquid chromatographytandem mass spectrometry. I. Profiling an unfractionated tryptic digest. Proteomics. 2001, 1, 93-107

10. Davis, M. T.; Spahr, C. S.; McGinley, M. D.; Robinson, J. H.; Bures, E. J.; Beierle, J.; Mort, J.; Yu, W.; Luethy, R.; Patterson, $\mathrm{S}$. D. Towards defining the urinary proteome using liquid chromatography-tandem mass spectrometry. II. Limitations of complex mixture analyses. Proteomics. 2001, 1, 108-117.

11. Simpson, R. J.; Connelly, L. M.; Eddes, J. S.; Pereira, J. J.; Moritz, R. L.; Reid, G. E. Proteomic analysis of the human colon carcinoma cell line (LIM 1215): Development of a membrane protein database. Electrophoresis 2000, 21, 17071732.

12. Oda, Y.; Huang, K.; Cross, F. R.; Cowburn, D.; Chait, B. T. Accurate quantitation of protein expression and site-specific phosphorylation. Proc. Natl. Acad. Sci. U.S.A. 1999, 96, 65916596.

13. Pasa-Tolic, L; Jensen, P. K.; Anderson, G. A.; Lipton, M. S.; Peden, K. K.; Martinovic, S; Tolic, N; Bruce, J. E.; Smith, R. D. High throughput proteome-wide precision measurements of protein expression using mass spectrometry. J. Am. Chem. Soc. 1999, 121, 7949-7950.

14. Ong, S.-E.; Blagoev, B.; Kratchmarova, I.; Bach-Kristensen, D.; Steen, H.; Pandey, A.; Mann, M. Stable isotope labeling by amino acids in cell culture, SILAC, as a simple and accurate approach to expression proteomics. Mol. Cell. Proteom. 2002, 1, 376-386.

15. Gygi, S. P.; Rist, B.; Gerber, S. A.; Turecek, F.; Gelb, M. H.; Aebersold, R. Quantitative analysis of complex protein mixtures using isotope-coded affinity tags. Nat. Biotechnol. 1999, 17, 994-999.

16. Smolka, M; Zhou, H.; Aebersold, R. Quantitative protein profiling using two-dimensional gel electrophoresis, isotopecoded affinity tag labeling, and mass spectrometry. Mol. Cell. Proteom. 2002, 1, 19-29.

17. Shiio, Y.; Donohoe, S.; Yi, E. C.; Goodlett, D. R.; Aebersold, R.; Eisenman, R. N. Quantitative proteomic analysis of Myc oncoprotein function. EMBO J. 2002, 21, 5088-5096.

18. Parker, K. C.; Patterson, D.; Williamson, B.; Marchese, J.; Graber, A.; He, F.; Jacobson, A.; Juhasz, P.; Martin. S. Depth of Proteome Issues: A yeast isotope-coded affinity tag reagent study. Mol. Cell. Proteom. 2004, 3, 625-659.

19. Mirgorodskaya, O. A.; Kozmin, Y. P.; Titov, M. I.; Korner, R.; Sonksen, C. P.; Roepstorff, P. Quantitation of peptides and proteins by matrix-assisted laser desorption/ionization mass spectrometry using ${ }^{18} \mathrm{O}$-labeled internal standards. Rapid Commun. Mass Spectrom. 2000, 14, 1226-1232.

20. Stewart, I. I.; Thomson, T.; Figeys, D. ${ }^{18} \mathrm{O}$ Labeling: A tool for proteomics. Rapid Commun. Mass Spectrom. 2001, 15, 24562465.

21. Yao, X.; Freas, A.; Ramirez, J.; Demirev, P. A.; Fenselau, C. Proteolytic ${ }^{18} \mathrm{O}$ Labeling for comparative oroteomics: Model studies with two serotypes of adenovirus. Anal. Chem. 2001, $73,2836-2842$.
22. Muenchbach, M.; Quadroni, M.; Miotto, G.; James, P. Quantitation and facilitated de novo sequencing of proteins by isotopic N-terminal labeling of peptides with a fragmentation-directing moiety. Anal. Chem. 2000, 72, 4047-4057.

23. Sechi, S. A method to identify and simultaneously determine the relative quantities of proteins isolated by gel electrophoresis. Rapid Commun. Mass Spectrom. 2002, 16, 1416-1424.

24. Geng, M.; Ji, J.; Regnier, F. E. Signature-peptide approach to detecting proteins in complex mixtures. J. Chromatogr. A. 2000, 870, 295-313.

25. Chakraborty, A.; Regnier, F. E. Global internal standard technology for comparative proteomics. J. Chromatogr. A 2002, 949, 173-184.

26. Ren, D.; Penner, N. A.; Slentz, B. E.; Mirzaei, H.; Regnier, F. E. Evaluating immobilized metal affinity chromatography for the selection of histidine-containing peptides in comparative proteomics. J. Proteom. Res. 2003, 2, 321-329.

27. Goodlett, D. R.; Keller, A.; Watts, J. D.; Newitt, R.; Yi, E. C.; Purvine, S.; Eng, J.; von Haller, P.; Aebersold, R.; Kolker, E. Differential stable isotope labeling of peptides for quantitation and de novo sequence derivation. Rapid Commun. Mass Spectrom. 2001, 15, 1214-1221.

28. Gehanne, S.; Cecconi, D.; Carboni, L.; Righetti, P. G.; Domenici. E.; Hamdan, M. Quantitative analysis of two-dimensional gel-separated proteins using isotopically marked alkylating agents and matrix-assisted laser desorption/ionization mass spectrometry. Rapid Commun. Mass Spectrom. 2002, 16, 1692-1698.

29. Shen, M.; Guo, L.; Wallace, A.; Fitzner, J.; Eisenman, J.; Jacobson, E.; Johnson, R. S. Isolation and isotope labeling of cysteine- and methionine-containing tryptic peptides: Application to the study of cell surface proteolysis. Mol. Cell. Proteom. 2003, 2, 315-324.

30. Kuyama, H.; Watanabe, M.; Toda, C.; Ando, E.; Tanaka, K.; Nishimura, O. An approach to quantitative proteome analysis by labeling tryptophan residues. Rapid Commun. Mass Spectrom. 2003, 17, 1642-1650.

31. Qiu, Y; Sousa, E. A.; Hewick, R. M.; Wang, J. H. Acid-labile isotope-coded extractants: A class of reagents for quantitative mass spectrometric analysis of complex protein mixtures. Anal. Chem. 2002, 74, 4969-4979.

32. Julka, S.; Regnier, F. Quantification in proteomics through stable isotope coding: A review. J. Proteom. Res. 2004, 3, 350-363.

33. Hansen, K. C.; Schmitt-Ulms, G.; Chalkley, R.; Hirsch, J.; Baldwin, M. A.; Burlingame, A. L. Mass spectrometric analysis of protein mixtures at low levels using cleavable ${ }^{13} \mathrm{C}$ isotope-coded affinity tag and multidimensional chromatography. Mol. Cell. Proteom. 2003, 2, 299-314.

34. Zhou, H.; Ranish, J. A.; Watts, J. D.; Aebersold, R. Quantitative proteome analysis by solid-phase isotope tagging and mass spectrometry. Nat. Biotechnol. 2002, 20, 512-515.

35. Zhang, R.; Sioma, C. S.; Wang, S.; Regnier, F. E. Fractionation of isotopically labeled peptides in quantitative proteomics. Anal. Chem. 2001, 73, 5142-5149.

36. Zhang, R.; Sioma, C. S.; Thompson, R. A.; Xiong, L.; Regnier, F. E. Controlling deuterium isotope effects in comparative proteomics. Anal. Chem. 2002, 74, 3662-3669.

37. Krutchinsky, A. N.; Chait, B. T. On the nature of the chemical noise in MALDI mass spectra. J. Am. Soc. Mass Spectrom. 2002, 13, 129-134.

38. Washburn, M. P.; Ulaszek, R. R.; Yates, J. R. Reproducibility of quantitative proteomic analyses of complex biological mixtures by multidimensional protein identification technology. Anal. Chem. 2003, 75, 5054-5061.

39. Washburn, M. P.; Koller, A.; Oshiro, G.; Ulaszek, R. R.; Plouffe, D.; Deciu, C.; Winzeler, E.; Yates, J. R. Protein 
pathway and complex clustering of correlated mRNA and protein expression analyses inSaccharomyces cerevisiae. Proc. Natl. Acad. Sci. U.S.A. 2003, 100, 3107-3112.

40. Thompson, A.; Schaefer, J.; Kuhn, K.; Kiene, S.; Schwarz, J.; Schmidt, G.; Johnstone, R.; Neumann, T.; Hamon, C. Tandem Mass Tags: A novel quantification strategy for comparative analysis of complex protein mixtures by MS/MS. Anal. Chem. 2003, 75, 1895-1904.

41. Schwartz, J. C.; Wade, A. P.; Enke, C. G.; Cooks, R. G. Systematic delineation of scan modes in multidimensional mass spectrometry. Anal. Chem. 1990, 62, 1809-1818.

42. Wilm, M.; Neubauer, G.; Mann, M. Parent ion scans of unseparated peptide mixtures. Anal. Chem. 1996, 68, 527-533.

43. Carr, S. A.; Huddleston, M. J.; Annan R. S. Selective detection and sequencing of phosphopeptides at the femtomole level by mass spectrometry. Anal. Biochem. 1996, 239, 180-192.

44. Weckwerth, W.; Willmitzer, L.; Fiehn, O. Comparative quantification and identification of phosphoproteins using stable isotope labeling and liquid chromatography/mass spectrometry. Rapid Commun. Mass Spectrom. 2000, 14, 1677-1681.

45. Schlosser, A.; Pipkorn, R.; Bossemeyer, D.; Lehmann, W. D. Analysis of protein phosphorylation by a combination of elastase digestion and neutral loss tandem mass spectrometry. Anal. Chem. 2001, 73, 170-176.

46. Steen, H.; Kuster, B.; Fernandez, M.; Pandey, A.; Mann, M. Detection of tyrosine phosphorylated peptides by precursor ion scanning quadrupole TOF mass spectrometry in positive ion mode. Anal. Chem. 2001, 73, 1440-1448.

47. Molloy, M. P.; Andrews, P. C. Phosphopeptide derivatization signatures to identify serine and threonine phosphorylated peptides by mass spectrometry. Anal. Chem. 2001, 73, 53875394.

48. Li, W.; Boykins, R. A.; Backlund, P. S.; Wang, G.; aChen, H.-C. Identification of phosphoserine and phosphothreonine as cysteic acid and $\beta$-methylcysteic acid residues in peptides by tandem mass spectrometric sequencing. Anal. Chem. 2002, $74,5701-5710$.

49. Steen, H.; Mann, M. A new derivatization strategy for the analysis of phosphopeptides by precursor ion scanning in positive ion mode. J. Am. Soc. Mass Spectrom. 2002, 13, 996-1003.

50. Back, J. W.; Hartog, A. F.; Dekker, H. L.; Muijsers, A. O.; de Koning, L. J.; de Jong, L. A new crosslinker for mass spectrometric analysis of the quaternary structure of protein complexes. J. Am. Soc. Mass Spectrom. 2001, 12, 222-227.

51. Dongre, A. R.; Jones, J. L.; Somogyi, A.; Wysocki, V. H. Influence of peptide composition, gas-phase basicity, and chemical modification on fragmentation efficiency: Evidence for the mobile proton model. J. Am. Chem. Soc. 1996, 118, 8365-8374.

52. O'Hair, R. A. J. The role of nucleophile-electrophile interactions in the unimolecular and bimolecular gas-phase ion chemistry of peptides and related systems. J. Mass Spectrom. 2000, 35, 1377-1381.

53. Schlosser, A.; Lehmann, W. D. Five-membered ring formation in unimolecular reactions of peptides: A key structural element controlling low-energy collision-induced dissociation of peptides. J. Mass Spectrom. 2000, 35, 1382-1390.

54. Wysocki, V. H.; Tsaprailis, G.; Smith, L. L.; Breci, L. A. Mobile and localized protons: A framework for understanding peptide dissociation. J. Mass Spectrom. 2000, 35, 1399-1406.

55. Kapp, E. A.; Schütz, F.; Reid, G. E.; Eddes, J. S.; Moritz, R. L.; O'Hair, R. A .J.; Speed, T. P.; Simpson, R. J. Mining a tandem mass spectrometry database to determine the trends and global factors influencing peptide fragmentation.Anal. Chem. 2003, 75, 6251-6264.
56. Reid, G. E.; Roberts, K. D.; Kapp, E. A.; Simpson, R. J. Statistical and mechanistic approaches to understanding the gas-phase fragmentation behavior of methionine sulfoxide containing peptides. J. Proteom. Res. 2004, 3, 751-759.

57. Knapp, D. R. Chemical derivatization for mass spectrometry. Methods Enzymol. 1990, 193, 314-329.

58. Anderegg, R. J. Derivatization in mass spectrometry: Strategies for controlling fragmentation. Mass Spectrom. Rev. 1988, 7, 395-424.

59. Roth, K. D. W.; Huang, Z.-H.; Sadagopan, N.; Watson J. T. Charge derivatization of peptides for analysis by mass spectrometry. Mass Spectrom. Rev. 1998, 17, 255-274.

60. Sadagopan, N.; Watson J. T. Mass spectrometric evidence for mechanisms of fragmentation of charge-derivatized peptides. J. Am. Soc. Mass. Spectrom. 2001, 12, 399-409.

61. Spengler, B.; Luetzenkirchen, F.; Metzger, S.; Chaurand, P.; Kaufmann, R.; Jeffery, W.; Bartlet-Jones, M.; Pappin, D. J. C. Peptide sequencing of charged derivatives by post-source decay MALDI mass spectrometry. Int. J. Mass Spectrom. Ion Processes 1997, 169/170, 127-140.

62. Keough, T.; Youngquist, R. S.; Lacey, M. P. Sulfonic acid derivatives for peptide sequencing by MALDI MS. Anal. Chem. 2003, 75, A156-A165.

63. Frechet, J. M. J.; Farrall, M. J.; Nuyens, L. J. Polymeric reagents. II. Synthesis and applications of crosslinked poly(vinylpyridinium hydrobromide perbromide) resins. J. Macromol. Sci. Chem. 1977, A11, A507-A514.

64. Liu, T.-H. The role of sulfur in proteins. In The Proteins, Vol. III; Neurath, H.; Hill, R. L.; Boeder, C.-L., Eds.; Academic: New York, 1977; Chap III, pp 239-402.

65. Stirling, C. J. M. The Chemistry of Functional Groups: The Chemistry of the Sulfonium Group, Pt. 1. John Wiley and Sons: Chichester, UK, 1981.

66. Lundblad, R. L. Techniques in protein modification. In The Modification of Methionine; CRC Press: Boca Raton, Florida, 1995; Chap. VIII.

67. Gundlach, H. G.; Moore, S.; Stein, W. H. The reaction of iodoacetate with methionine. J. Biol. Chem. 1959, 234, 17611764.

68. Rogers, G. A.; Shaltiel, N.; Boyer, P. D. Facile alkylation of methionine by benzyl bromide and demonstration of fumarase inactivation accompanied by alkylation of a methionine residue. J. Biol. Chem. 1976, 251, 5711-5717.

69. Toennies, G.; Kolb, J. J. Methionine studies. VII. Sulfonium derivatives. J. Am. Chem. Soc. 1945, 67, 849-851.

70. Lavine, T. F.; Floyd, N. F.; Cammaroti, M. S. The formation of sulfonium salts from alcohols and methionine in sulfuric acid.J. Biol. Chem. 1954, 207, 107-117.

71. Lawson, W. B.; Schramm, H. J. Modification of a methionine residue near the active site of chymotrypsin. J. Am. Chem. Soc. 1962, 84, 2017-2018.

72. Gross, E. Cyanogen bromide reaction with peptides. Methods Enzymol. 1967, 11, 238-255.

73. Tang, J. R.; Hartley, B. S. A diagonal electrophoretic method for selective purification of methionine peptides. Biochem. J. $1967,102,593-599$

74. Gairi, M.; Lloyd-Williams, P.; Albericio, F.; Giralt, E. Severe side-reaction in the acidolytic cleavage of a C-terminal Metcontaining peptide from the solid support. Formation of the homoserine lactone peptide. Tetrahedron Lett. 1994, 35, 175178.

75. Taylor, K. L.; Pohl, J.; Kinkade, J. M. Unique autolytic cleavage of human myeloperoxidase. Implications for the involvement of active site Met409. J. Biol. Chem. 1992, 267, 25282-25288. 
76. Kyte, J.; Degen, J.; Harkins, R. N. Purification of peptides that contain methionine residues. Methods Enzymol. 1983, 91, 367-377.

77. Weinberger, S. R.; Viner, R. I.; Ho, P. Tagless extractionretentate chromatography: A new global protein digestion strategy for monitoring differential protein expression. Electrophoresis 2002, 23, 3182-3192.

78. Chassaing, G.; Lavielle, S.; Marquet, A. Transformation of methionine into S-tert-butylhomocysteine. Application to a methionine-containing peptide: Substance P. J. Org. Chem. 1983, 48, 1757-1760.

79. O'Hair, R. A. J.; Reid, G. E. Neighboring group versus cis-elimination mechanisms for side chain loss from protonated methionine, methionine sulfoxide, and their peptides gas-phase ion chemistry of biomolecules. Eur. Mass Spectrom. 1999, 5, 325-334.

80. Reid, G. E.; Simpson, R. J.; O'Hair, R. A. J. Leaving group and gas phase neighboring group effects in the side chain losses from protonated serine and its derivatives. J. Am. Soc. Mass Spectrom. 2000, 11, 1047-1060.

81. Foti, S.; Saletti, R.; Marletta, D. Partial methanolysis and fast atom bombardment mass spectrometry of peptides containing sulfurated amino acids. Org. Mass Spectrom. 1991, 26, 903-907.

82. Lapko, V. N.; Smith, D. L.; Smith, J. B. Identification of an artifact in the mass spectrometry of proteins derivatized with iodoacetamide. J. Mass Spectrom. 2000, 35, 572-575.

83. Stirling C. J. M. Sulfonium salts in organic chemistry of sulfur Oae, S. Ed.; Plenum Press: New York, 1977; Chap. IX, pp 473-525.

84. Capozzi, G.; Modena, G. Reactive sulfonium salts. Stud. Org. Chem. 1985, 19, 246-298.

85. March, J. Advanced Organic Chemistry, 4th ed.; Wiley: New York, 1992; p 343.

86. Halvorsen, S. The reactivity of 2-bromo-1-phenylethanone (phenacyl bromide) toward nucleophilic species. J. Chem. Soc. Chem. Commun. 1978, 327-328.

87. Yoh, S. D.; Lee, O. S. A multiple Hammett study of the nucleophilic substitution reaction of a-carbonyl derivatives. Tetrahedron Lett. 1988, 29, 4431-4434

88. Scheitjter, A.; Aviram, I. Reversal of the alkylation of the methionine residues of cytochrome c. FEBS Lett. 1972, 21, 293-296

89. Toennies, G.; Kolb, J. J. Methionine Studies. VIII. Regeneration of Sulfides from Sulfonium Derivatives. J. Am. Chem. Soc. 1945, 67, 1141-1144.

90. Naider, F.; Bohak, Z. Regeneration of methionyl residues from their sulfonium salts in peptides and proteins. Biochemistry 1972, 11, 3208-3211.
91. Cantoni, G. L. Onium compounds and their biological significance. Comp. Biochem. 1960, 1, 181-241.

92. Trost, B. M.; Melvin, L. S. Organic Chemistry, Vol. 31: Sulfur Ylides: Emerging Synthetic Intermediates. Academic Press: New York, 1975.

93. O'Hair, R. A. J.; Freitas, M. A.; Gronert, S.; Schmidt, J. A. R.; Williams, T. D. Concerning the regioselectivity of gas-phase reactions of glycine with electrophiles. The cases of the dimethylchlorinium ion and the methoxymethyl cation. J. Org. Chem. 1995, 60, 1990-1998.

94. Mudd, W. A.; Klee P. D. Enthalpy changes accompanying the transfer of a methyl group from $S$-adenosylmethionine and other sulfonium compounds to homocysteine. Biochemistry 1966, 5, 1653-1660.

95. Deakyne, C. A; Knuth, D. M.; Meot-Ner, M; Breneman, C. M.; Liebman, J. F. Experimental and theoretical study of the energetics of trialkylsulfonium ions. J. Mol. Struct. 1999, 485/486, 33-41.

96. Markham, G. D.; Bock, C. W. Structural and thermodynamic properties of sulfonium ions: An ab initio molecular orbital study. J. Phys. Chem. 1993, 97, 5562-5569.

97. Katritzky, A. R.; Shipkova, P. A.; Watson, C. H.; Eyler, J. R.; Kevill, D. N. Gas-phase investigations of sulfonium salts by electrospray FT-ICR/MS. Int. J. Mass Spectrom. 1997, 165/166, 577-583.

98. Buckley, N.; Maltby, D.; Burlingame, A. L.; Oppenheimer, N. J. Reactions of charged substrates. 4. The gas-phase dissociation of (4-substituted benzyl)dimethylsulfoniums and -pyridiniums. J. Org. Chem. 1996, 61, 2753-2762.

99. Mestdagh, H.; Morin, N.; Rolando, C. Sulfonium ions: Collision-activated dissociation using fast atom bombardment ionization and a triple quadrupole mass spectromter. Org. Mass Spectrom. 1986, 21, 321-327.

100. Mestdagh, H.; Morin, N.; Rolando, C. Comparison of low energy CAD spectra of sulfonium, ammonium, and phosphonium cations. Propene elimination from allyl-substituted oniums. Org. Mass Spectrom. 1988, 23, 246-251.

101. Gerber, S. A.; Rush, J.; Stemman, O.; Kirschner, M. W.; Gygi, S. P. Absolute quantification of proteins and phosphoproteins from cell lysates by tandem MS. Proc. Natl. Acad. Sci. U.S.A. 2003, 100, 6940-6945.

102. Gevaert, K.; Van Damme, J.; Goethals, M.; Thomas, G. R.; Hoorelbeke, B.; Demol, H.; Martens, L.; Puype, M.; Staes, A.; Vandekerckhove, J. Chromatographic isolation of methionine-containing peptides for gel-free proteome analysis: Identification of more than 800 Escherichia coli proteins. Mol. Cell. Proteom. 2002, 1, 896-903.

103. Ren, D.; Julka, S.; Inerowicz, H. D.; Regnier, F. E. Enrichment of cysteine-containing peptides from tryptic digests using a quaternary amine tag. Anal. Chem. 2004, 76, 4522-4530. 